\title{
قياس درجة رضا طلبة كلية العلوم التطبيقية بصحار عن خبراتهم الأكاديمية والإدارية
}

حمدة بنت حمد بن هلال السعدية*

كليـة العلوم التطبيقية بادرستاق، سلطنـة عمـان

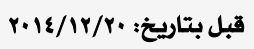

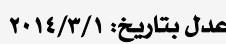

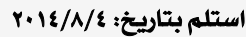

هدفت الدراسة إلى التعرف على مدى درجة رضا طلبة كلية العلوم التطبيقية بصحار عن خبراتهم الأكاديمية والإدارية، والتعرف على أثر الثرا

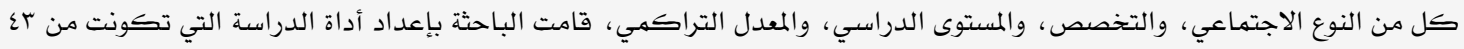

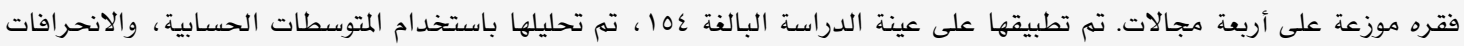

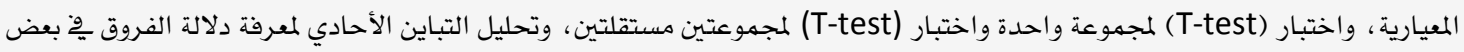

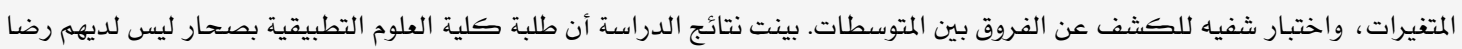

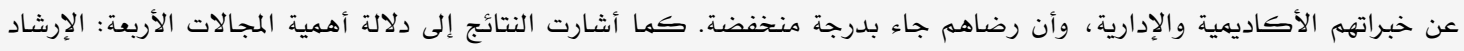

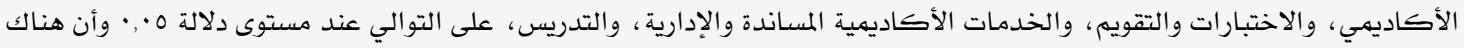

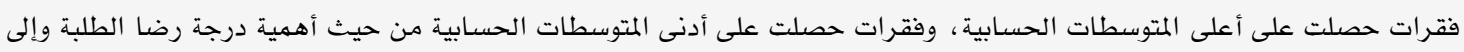

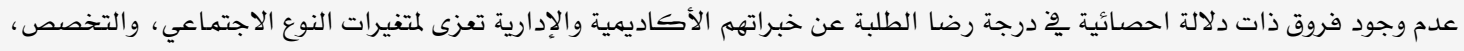

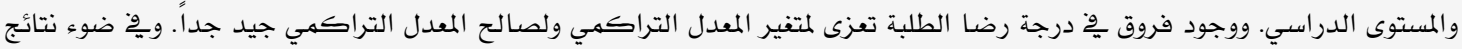

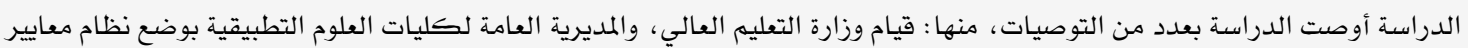

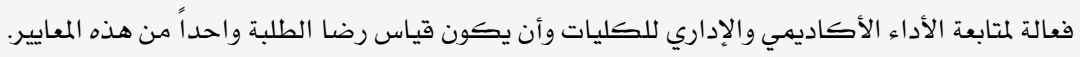
الكلمات المفتاحية: الرضا ، الخبرات الأكاديمية والإدارية، كلية العلوم التطبيقية.

\section{Measurement of Sohar Students' Satisfaction Degree with their Academic and Administrative Experience}

Hamda H. Al-saadi*

Al Rustaq College of Applied Sciences, Sultanate of Oman

The study aimed to measure the degree of satisfaction with the academic and administrative experience of the students of Sohar College of Applied Sciences and to know the effect of the social, specialty, study level and GPA variables. To achieve the aim of the study the researcher prepared a questionnaire of 43 items covering four areas. It was applied to the study sample which included 154 students. Data were collected and analyzed using the Mean, Standard Deviation, and T-test for one group and two independent groups, unidifferential analysis to know the significance of the differences among some variables and Scheffe Test to disclose differences among the means. The study results stated that the CAS - Sohar students have not been satisfied with their academic and administrative experience. The satisfaction is low. The results also have pointed out to the significance of the four areas at the significance level of $0.05 \%$. Some items have got the highest mean while some others have got the lowest mean regarding the importance of the students' satisfaction. The results have shown no differences of statistical significances in the level of the students satisfaction attributed to the social, specialty and study level variables. There were differences in the degree of satisfaction attributed to the GPA variable and in favor of the GPA with Very Good. The study recommended the folowing: The Ministry of Higher Education and the Directorate General of the Colleges of Applied Sciences should set effective criteria for the follow up of the academic and administrative performance of the colleges and students' satisfaction should be one

Keywords: satisfaction, academic and administrative experiences in CAS -Sohar.

*hamda hamad2001@yahoo.com 
الــذي يعيثــة العــاملون والطلبــة فـــي النظــام

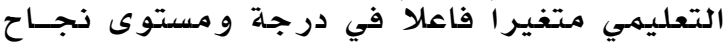

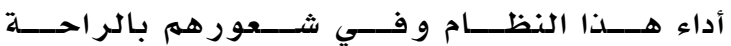

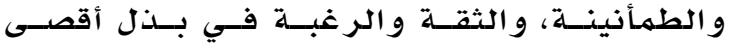

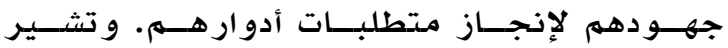

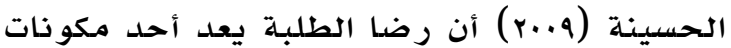
إدارة الجودة الشاملـة فـي المؤسســات التعليميــة،

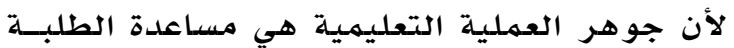
على تحصيل الهعارف و الههــارات فيهـا. و غيـاب

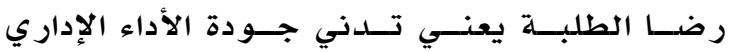

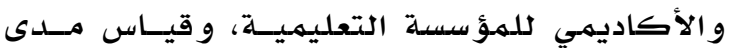
رضا الطلبــة عـن أداء الهمؤسســة يعـد مــن أهــم

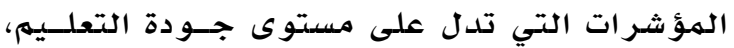
و تساعد الإدارة على وضع استراتيجيتها وخطتهـا لرفع المستوى التعليهي. ويعرف العديد من الباحثين الرضا بمفاهيم مختلفة حيث يعرف كوتلر (Kotler, 2001) الرضا بأنه هو الشعور بالسعادة والابتهاج الذي رهاي يحصل عليهما الإنسان نتيجة إثباع حاجـة أو فرو رغبة عنده. فالإشباع في مهال الأعمال و الخدمات، كرضا الهستهلك هو ما يحققه من منفعة من خلال الستهلاكه لسلعه ما أو انتفاعه ماكه من خدمـة ما. ويمكن أن يعرف رضا الزبون بأنه درجة إدراكه لمـدى فاعلية المنظمهة، في تقديم

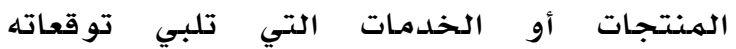
و حاجاته. فالرضا هو دالة على الأداء و المدررك و المتوقع من قبل الزبون، ففي حالة عجز الأداء عن المتوقع فإن الزبون يكون في حالة عدام

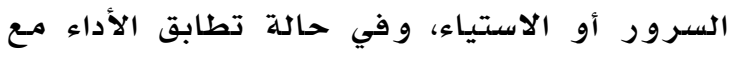
المتوقع فإن الزبون سيشعر بالسعادة و الرضا.

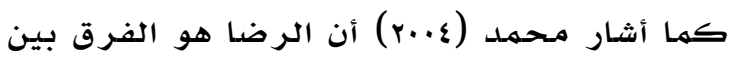

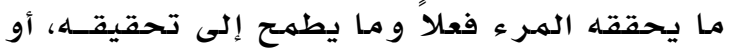
الفرق بين شـعور الثـخص تجسـاه مسا ينبغسي أن يحصل عليه، ووما يدرك الشخص أنه حاصل عليه آنه

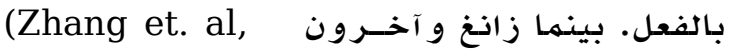

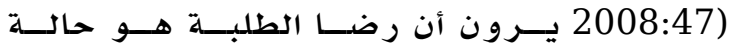
الشـعور المـرضـيـة مـن الطلبـة نتيجسـة لنجــاح

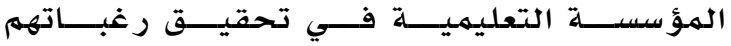

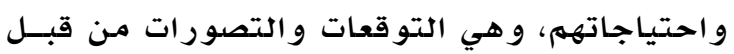

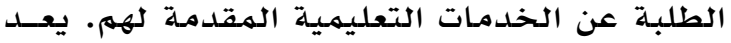

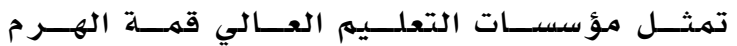

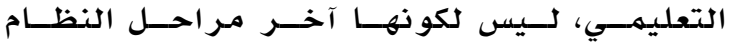

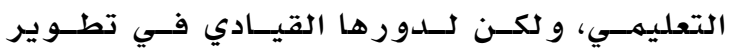

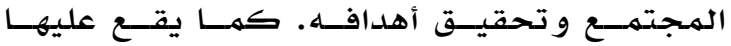

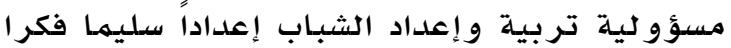

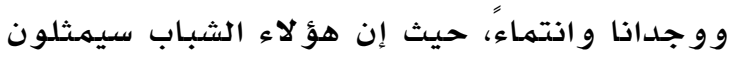
قيادات المـجتمـع مستقبلا فـي مختلــف المجــالات

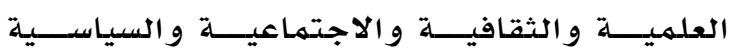

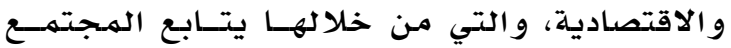

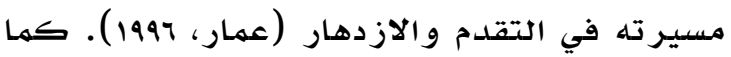
تعد الدراسـة الجـامعية إحلدى قنوات الإعـداد التـي التهي تهيئ الشباب لقيادة الهـتمعات وتحمل مسؤو ليته

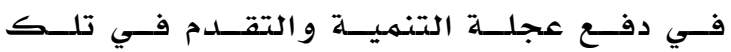
المجتمعات، و لكي تقوم الجامعة بتأديـة رسـالتها

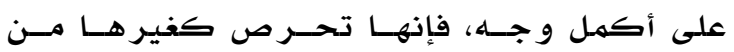
الهمؤسسات التعليمية عند إعداد بر امجها علـى أن أن

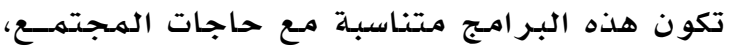
و في الوقت ذاته تحر ص الجامعة على قبول نخبـة

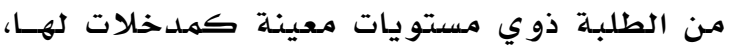

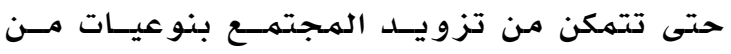

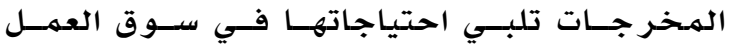

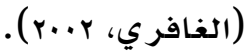

فالجامعة تجربسة جديـدة للطلبــة، تختلـف عـن التجارب التعليميـة السـابقة ففيهـا الكثيـر مسنـ

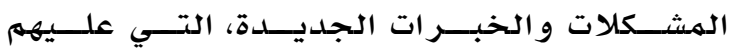
اجتياز هــا، و مواجهتهــا، و التكيــف معهــا مثـلـئ التعرف على أنظمة الجـامعة و لوائحهـا، و اختيـار التخصــص، و التكيـف معــه، و الاختيــار الهـهنـي،

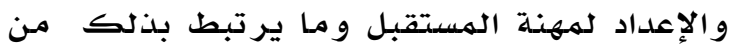

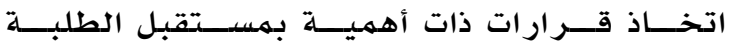
وحياتهم العلمية، وجودة حياتهم (سليمان، ·. (r).

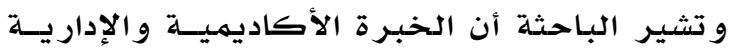
للطلبـة تأتي مـن خلال امتزاج الطلبة مـع بعضـهم

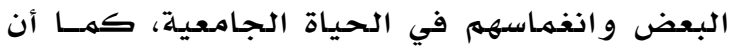

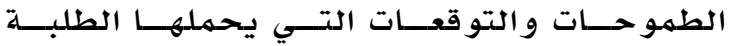
تساعدهم على التكيف في الحياة الجامعية. ويرى

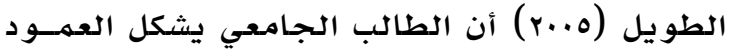
الفقري في الجـامعة وهو الأسـاس الذي من أجلسه

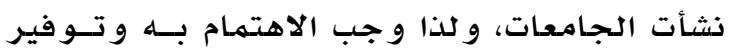
الهناخ الهناسب لله، إذ يشكل جو العهـل و الهـــاخ 


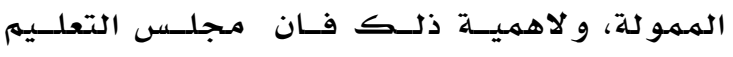

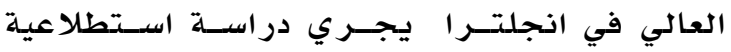

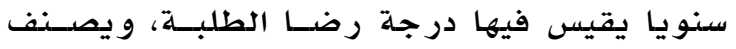
الجامعات حسب هذا المعيار فقد حصسلت جامعسـة

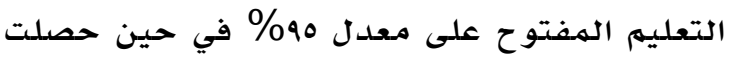

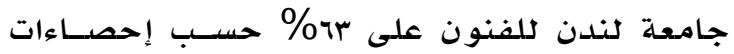

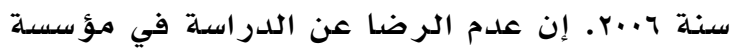

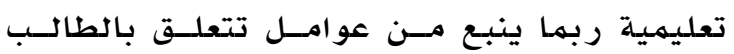

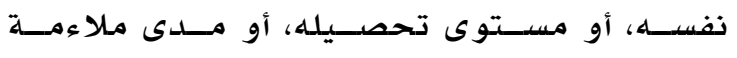

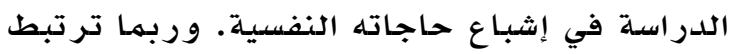

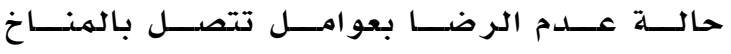

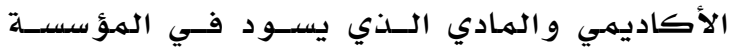

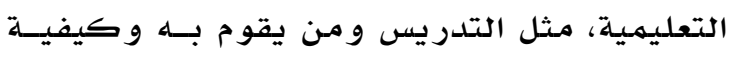
تقديمهه أو طرق تقــويهم أعضــاء هيئسـة التـدريس

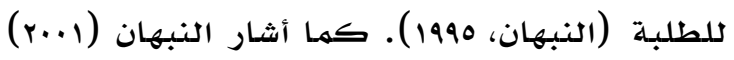
إلى أن عدم الرضا عن الدراسـة في الجامعة ربهـا يعود إلى عوامل تتعلق بالطالب نفسه، و تتهـثل في ضعف حبه للههنـة التي ستؤول إليها دراسـته، أو أو أن هناك سببياً يتصل بذكاء الهـتعلهم، أو مســتوى

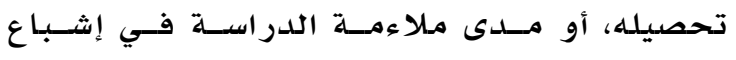
حاجاته النفسية، كما أن حالة الرضا قد تـرتبط

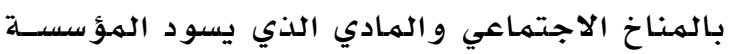

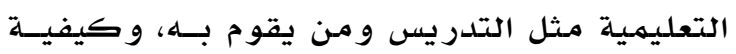

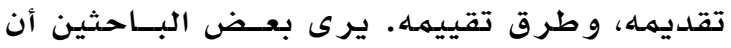

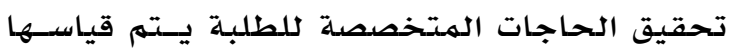
مـن خلال درجلة رضا الطلبـة عن الخــدمات التـي

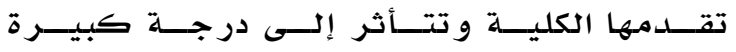

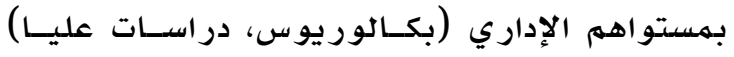
كمـا تتسأثر بتخصصـاتهم الأكاديميسة، وحجـهم العهل الهطلوب مــنهم، وبــين تقدير اتـه لفعاليـة أساتذته في الجامعة.

و تبادر معظم مؤسسـات التعليم العالي فـي جميــع

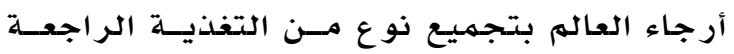

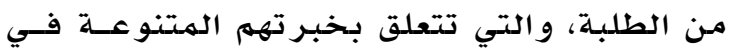

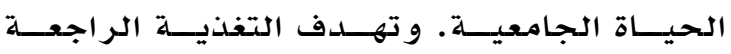

الصادرة من الطلبة إلى تحقيق وظيفتين هما: 1. معلومات داخلية لتوعية عملية التحسين.

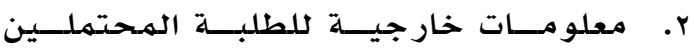

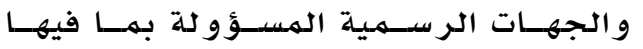

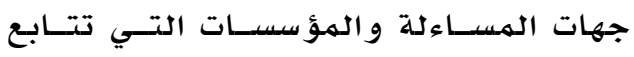

الرضـا الدراسي أحد الهؤشــرات الجيــدة و الدالــة

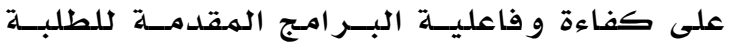

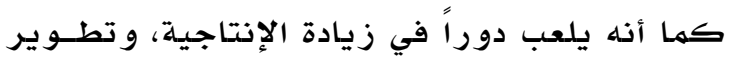

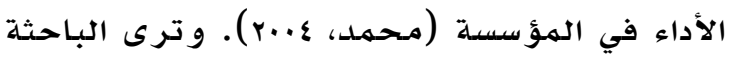

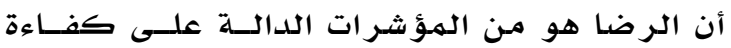

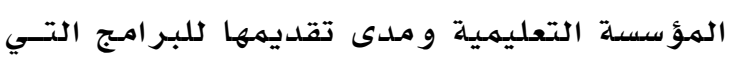
يستفيد منها الطلبـة في مستقبلهم الههني، وهــذا

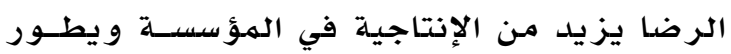

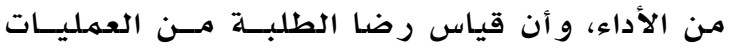

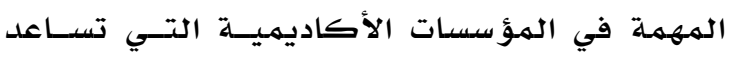
على صنـع القرارات المـناسـبـة فـي حيــاة شـؤون الهون الطلبـة الجامعية.

كمـــا أن قيــاس رضـــا الطلبـــة عمليــة مهمـــة

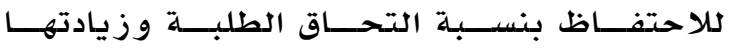

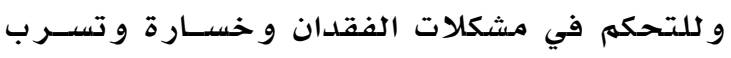
الطلبة الجامعيين، وون أجل اتخاذ قرارات أفضل

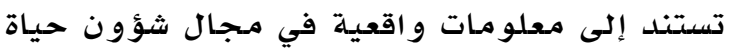

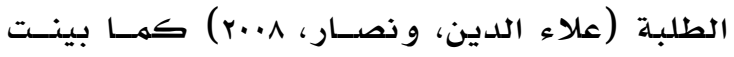

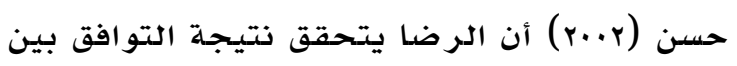

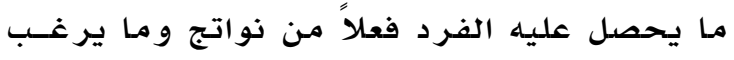

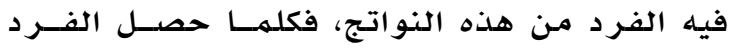

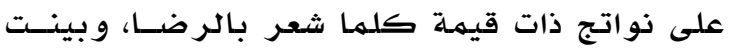
أن الرضا يمكن أن يتحدد بعدد من العوامل منها:

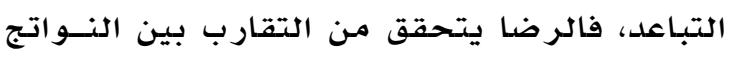

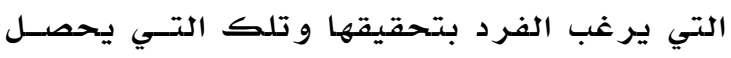

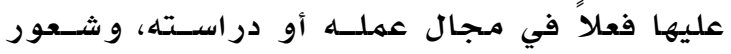

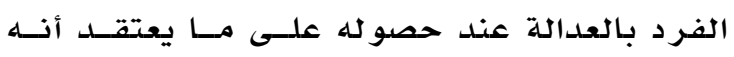
يستحقه و الهـوقف الشخصي الهســبق للفــرد قـــ

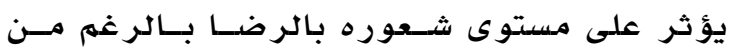
المتغير ات الإيجابية في البيئة. و تشير الباحثة إلى إن معرفة الرضا عن الخبرات

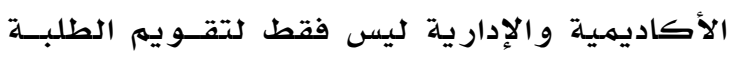

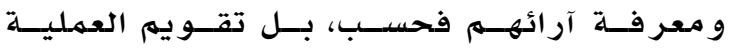

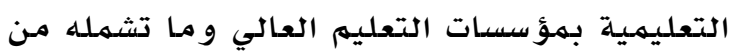
أعضــاء هيئــات تدر يســية و مســـاندة، و المـنــاهـج

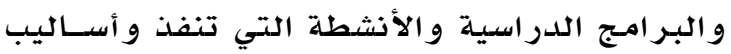

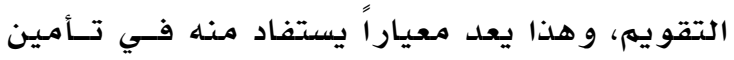

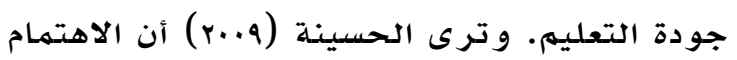

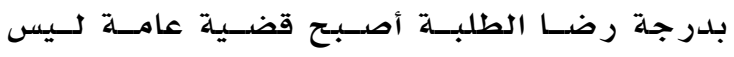
للطلبة وذويهم فقط بل تهم المـجتهـع، والجهـات الجهات 
المهحاضـرة، فالطلبـة يقيمون المهاضر على أسـاس نقاط كثيرة منهــا: تـدريس الطلبـة بهسـتوى يتلاءم مـع مستواهم الأكاديهي، بحيسث يمتلكسون

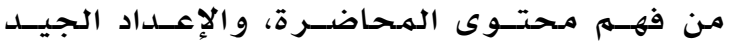
للهـحاضرة، و التنظظيم الجيـد لأفكـار الهحاضـر و عر ضها بصورة متسسلسلة خلال الفصل الدراسي. أمـا في مـجـال الاختبــارات فـإن هنــاك مـجمو عــة عوامل تؤثر في مستتوى الرضا عن الدراســة فـي مســتويات التعلــيم العـالي تتمثـل فــي مـر اعـاة

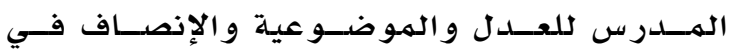
عمليــات تقيـيهم أداء الطلبــة، بغـض النظـر عـن معتقداتهم و اتجـاهاتهم الفكرية، و الحــرص على مرراقبتهمم خلال الامتحانات، و الحزم و الجدية في

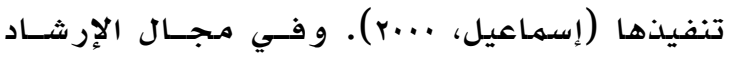
الأكـاديهـي فـإن الهـرشــد الأكــاديهي يجــبـ أن يجيب عن تساؤ لات الدارسين في القضـايا غيـر

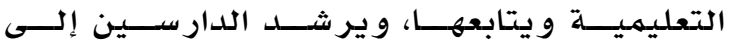
الهقررات التي عليهم التسـجيل فيهـا، ويسـاعدهم في اختيار الخطط الدراسـيـة، ويـدعم الدسارسـين أثناء الفهل الدراسي و يلبي احتياجاتهم الهتتعلقة ببيئهة الدراسـة والهقـررات الأكاديهيــة، ويرشـــ الطلبـة إلى فهم نظام التعليهم في جامعتهم، ويكون الصلة بين الجـامعة (الشؤون العلهيـة ) و الــدارس الس عبر الركلية، و يعالج أي مشكلات تتعلق بالتسـجيل و الرسوم و غيرها ها (محهمد، ال...r).

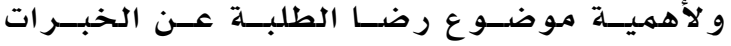
الأكاديميـة والإدارية في مؤسسات التعليهم العالي فقد أجريت العديد مـن الدراسـات في كثيـر مــن دو ل العالم لهعر فة مدى مسـتويات الرضـا عنــد الطلبـة وقياسها، والعوامل التــي تـؤثر فـي عـــم رضاهم و مـن هذه الدراسـات: فقد أجررت العلويسة

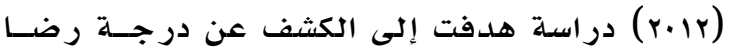

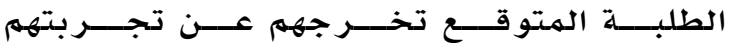
الأكاديميـة في الجـامعات الخاصلة بسلطنة عمـان، طبقت أداة مكونة من خمسسة مـحسـاور علـى عينــة عشوائية طبقية مكونة من عاء طالب و طالبـه مسـن ثلاث جامعات خاصــة فـي السـلطنة هـي جـامعـة صحار، ونزوى ، وظفار ومـن أبرز النتـائج التـي توصلت اليها الدراسلة أن درجة رضا الطلبة كان متوسط في المستوى العام، و لا توجد فروق دانة
التزام المؤسسات الجامعية ببعض الشروط الشـ الرئيسية لضمان استمـراريتها.

و تتضـهمن التغلذيسة الر اجعسة آراء الطلبــة بشــأن الخدمات التي يحصلون عليها كطلبـة فـي تلــك المؤسسات. كما وقد تتضهـن إدراكـاتهم بشــأن التدريس والتعليه، وبتسهيلات دعم عملية التعلهم

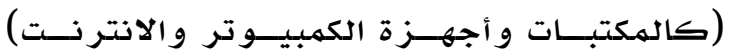

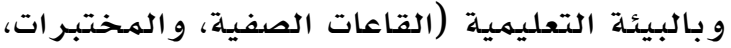

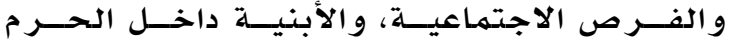

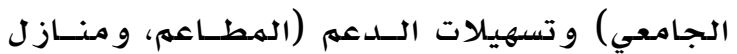

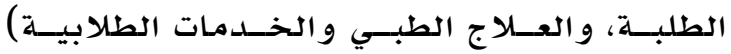
و الجوانب الخارجية المتعلقة بالطالب (كالأمور

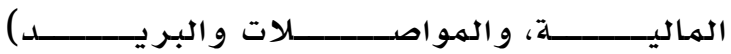

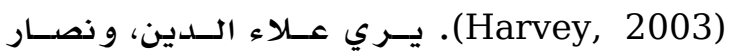

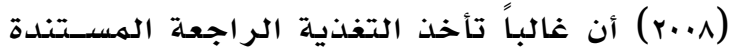
إلى الاستبـانات كصورة مسـوحات رضـا الطلبـة

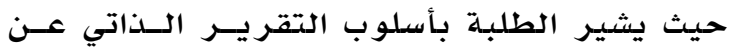
رضاهم عن الخبرة الجـامعية.

إن سعي الجامعة لتقديه خدمة تعليمية ذات جودة

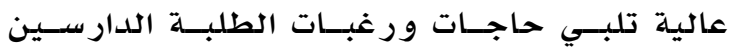
سيعزز بالتأكيد من العلاقة الإيجابية للطلبة في

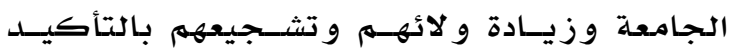

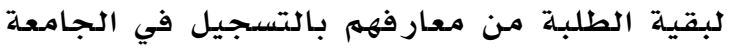

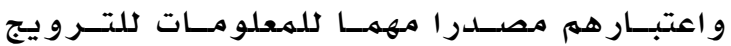

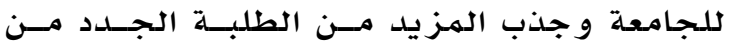

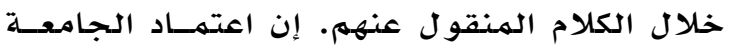

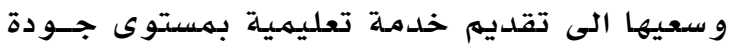
عالية يعد استر اتيجية أسـاسـية لتحقيـق النجــاح

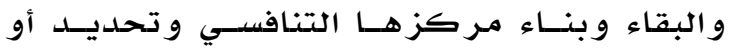

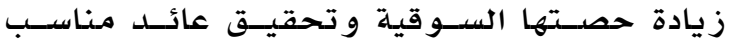

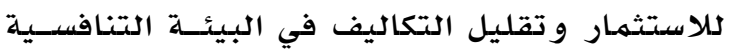

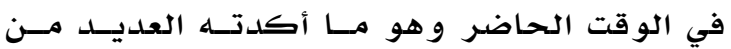

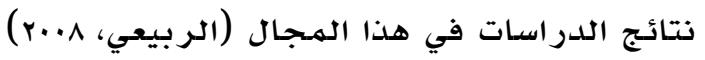

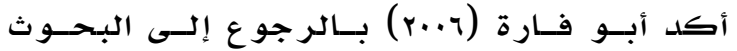

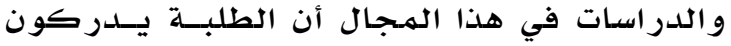

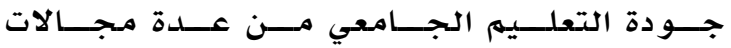
و مـوضدوعات مهمهة، منها المـحاضر الجــامعي فهـو

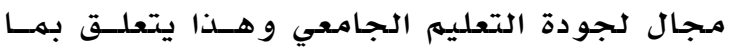

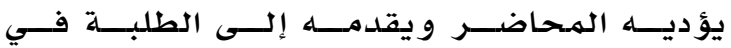


معرفة مستوى جودة الحياة جـدى طلبـة جامعسة

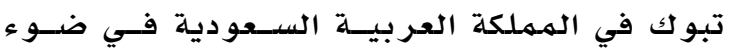

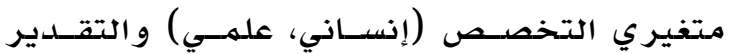

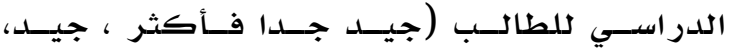

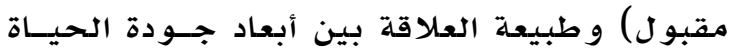

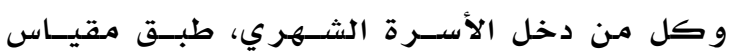

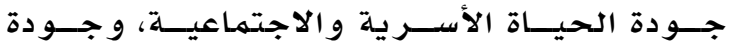

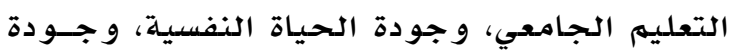
إدارة الوقت. أثـارت نتـائج الدراســة أن مســوى

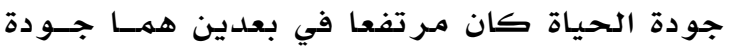

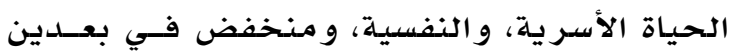

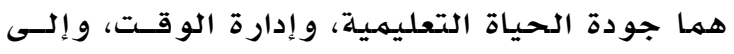

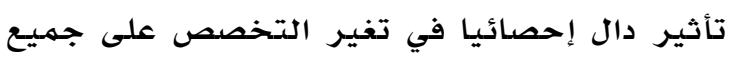
الأبعاد باستثناء جودة إدارة الوقتئ.

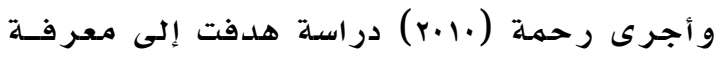
أراء طلبـة جامعة دمشق في أساليب تعامل إداريي

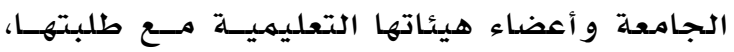

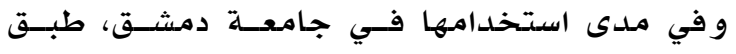

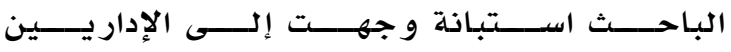

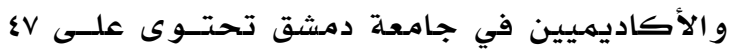

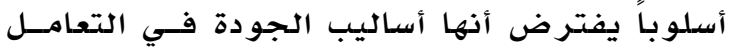

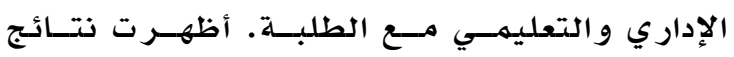

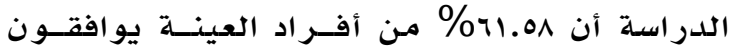

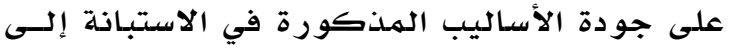

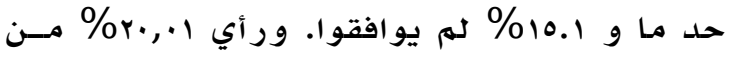

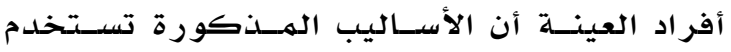

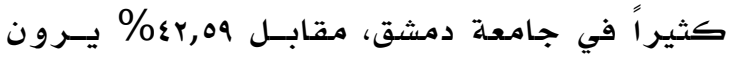

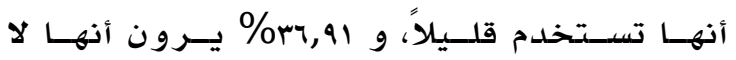

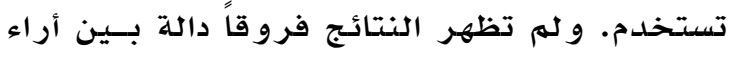
الذكور و الإناث و كذلك بين آراء طلبة الكليات

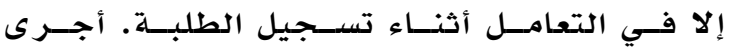

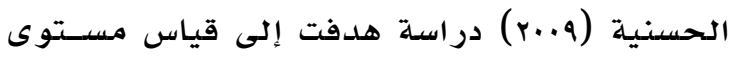

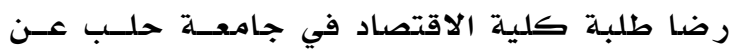

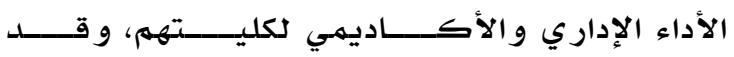

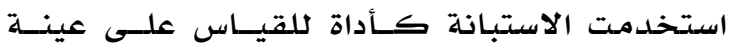

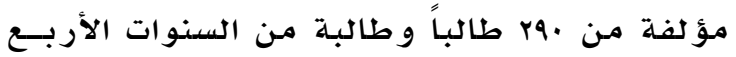

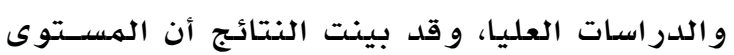

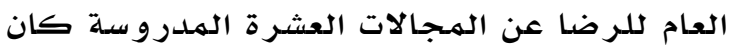
يتر اوح بين الجيد في مـجـال أداء أعضــاء الهيئسـة

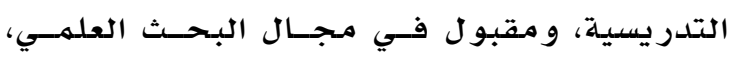

إحصائيا في درجهة الرضا تعـزى لمتغيـر النـوع الاجتهاعي، بينها توجد فروق دالة إحصائيا تعزى

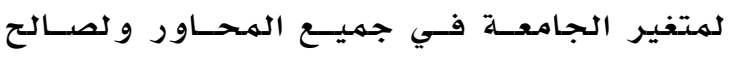

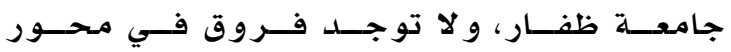
التـدريس و البحث العلهـي، و عــدم وجــود فــروق

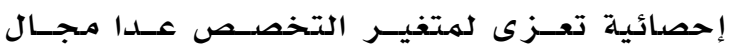
الدعم والإرشاد الأكاديهي. كمها أجرى العهمرات،

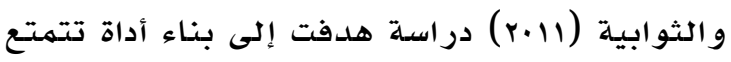

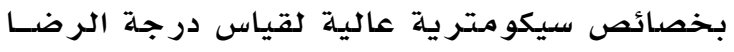

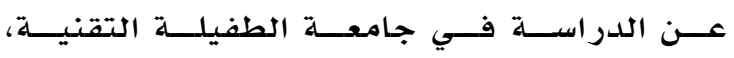

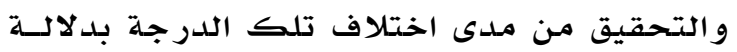

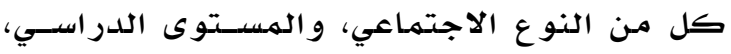

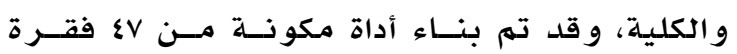

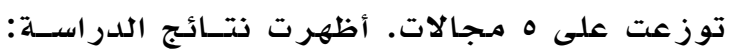

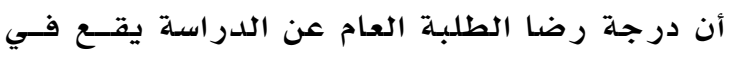

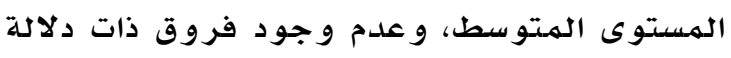

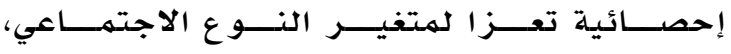
و المستوى الدراسي في تقدير درجة الر ضدا، فـي حين كانت هناك فروق ذات دلالة إحصـائية فـي

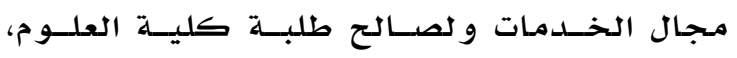
و كلية التربية، و فروقا ذات دلالة إحصائي لأثـر

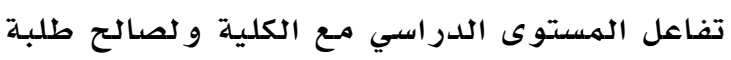

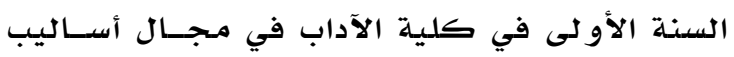

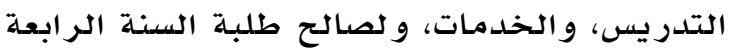
في كلية الآداب في مجال الإرشاد الأكاديمي. قام حســن، و آخــرون (11) بــار اســة اسـتهدفت

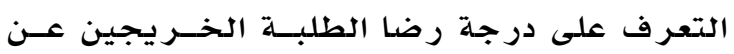

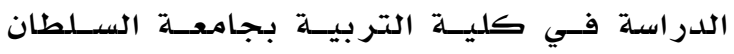

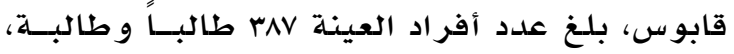

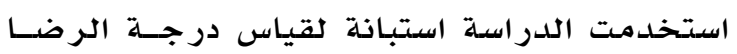
تكونت من V9 فقرة. أشـارت نتائج الدر اسـة إلى أن

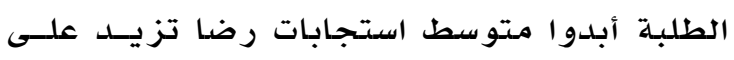

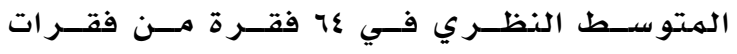

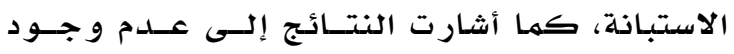

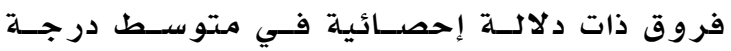

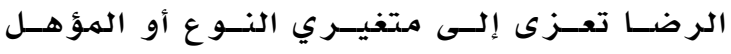

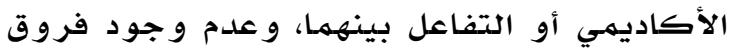
في الخبرات التي اكتسبها الطلبــة حسـب أبعـاد

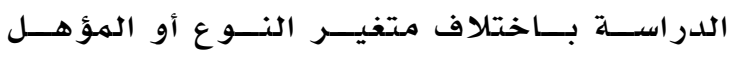

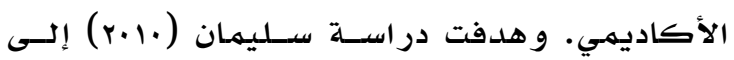


راضيين بلدرجة كافية عن الإشراف الأكــاديمي،

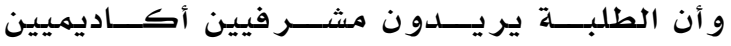

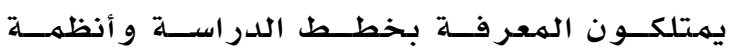
الجامعة، وأن الطلبـة الذين يشرف عليهم أسـاتذة عمانيين أكثر رضا عن الإشر اف الأكاديهي مسن

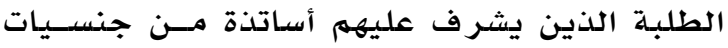
أخرى، وأن طلبـة كلية التربية أكثر رضـا مسن

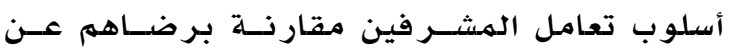
المعحلو مات التي يمتلكها المشرفين.

(Kara \& Deshields, أجسرى كــارا وديثـيلدا

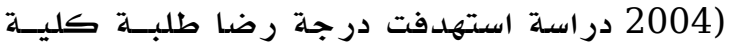

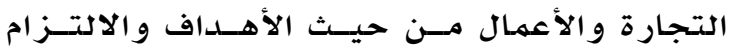
بالتعليهم الجامعي، و توضيـح العلاقــة بـيـن درجــة رضا طلبة كليسة التجــارة والأعمـال وأهـدافهم

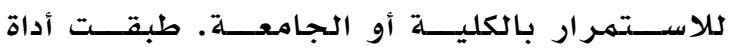
الدر اسـة على عينـة تكونت من •17 طالبـا و طالبـة مـن طلبــة جامعسة يـورك فـي و لاليسة بنســلفانيا

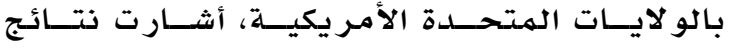
الدراسـة أن الطلبة الذين لهم اتجاهات إيجابية مـع

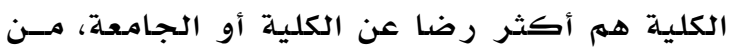
الطلبة الذين لا يهتلكون أي اتجاهات إيجابية مـع

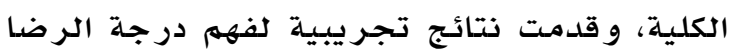

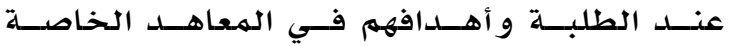

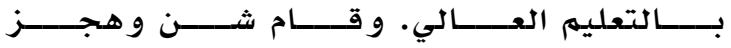
(Chen \& Hughes, 2004)

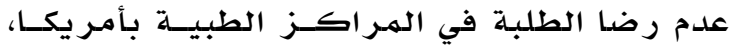

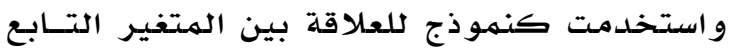

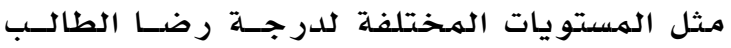

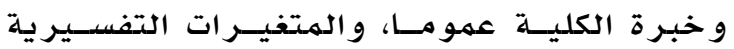
و الاهتهمام بالتكوين السديمغر افي للسـكان، و بيئسـة

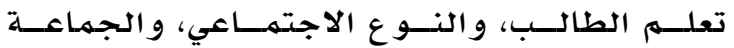

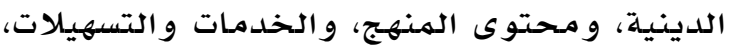

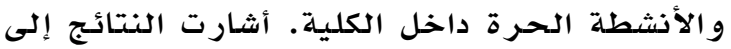

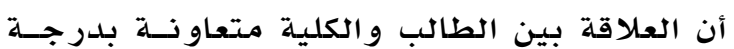
عالية، وأن العنصر الوحيد للهمنهج الطبـي يلبـي احتياجات الطالب وبلدوره يسهـ في تحقيق هدف

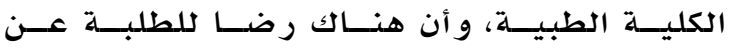
الوظائف التعليمية التي تقدمها الكلية لهم. قام أبو قديس (r...r) بدراسـة هدفت إلى معرفـة درجة رضا طلبـة الدفعـة الأو لـى التـي التحقـت
وضعيف في المجالات الأخرى جميعها، و لا توجد فروق في مستوى الرضــا تعـود إلـى المتغيــر ات

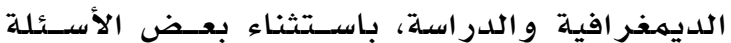
الهـحددة.

و هدفت دراسة بوماه (Boamah, 2009) إلى بناء مقياس لدرجة رضا الطلبة عن الخدمات المقدمـة من الكلية كنموذذج حديث. وتحديد ما إذا كانت درجلة رضا الطلبـة تختلف حسب السنـة الدراسـيـة بالكليسة مــع الخـــمـات الهقدمسـة لهـهم وتشــــل

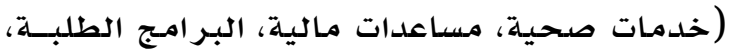

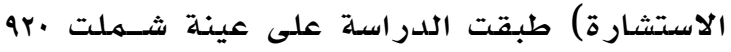

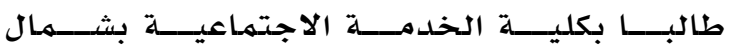
كاليفورنيا بأمـريكا. أثــارت نتـائج الدراســة أن طلبة السنـة الأولى يشعرون بدرجلة رضا كبيسرة

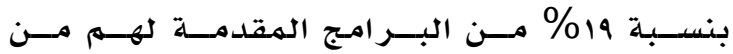
الجامعة، كما هدفت دراسـة علاء الـدين، ونصــار

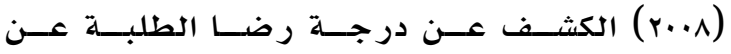
الخبر ات الجـامعية بعامليهـا الأكــاديهي و الإداري و ذلك لدى عينة عشوائية مؤلفة مـن ·Vـ طالبـاً

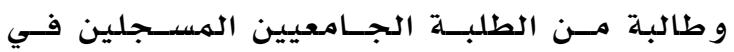
مستوى البكالوريوس في الجامعة الهاشهية، كما

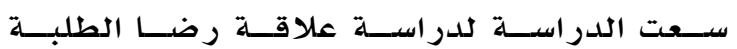
بمتغير ات الجنس، و المستوى الدر اســي و المعـدل التر اكهي، ومستوى تعلهم الوالدين. أشـارت نتائج

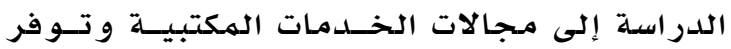
شروط السلامـة والإرشـاد الأكــاديمي وومسـتوى الأسى

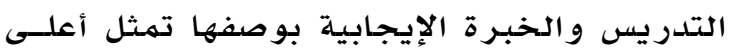

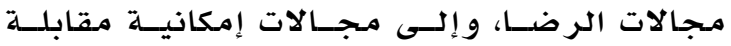

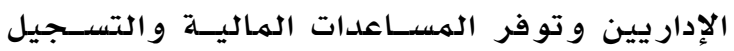

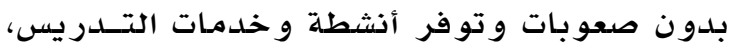
و تعامل المـلـرسين مـع الطلبــة علــى أســاس مــن

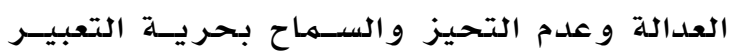

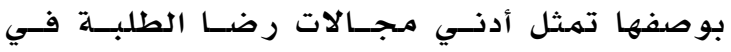

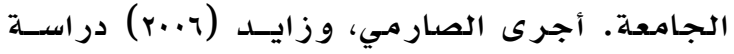
هدفت إلى التعرف فلى ملدى رضديا طلبـة كليـة

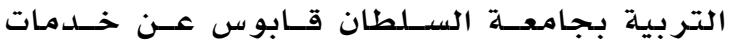

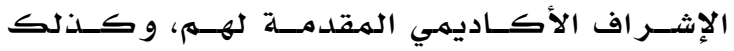
استطلاع توقعاتهم منها، تم تطبيق اسـتبانة علـى

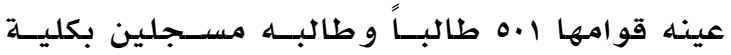
التربيـة. كشفت نتائج الدرراســة أن الطلبـة غيسر 


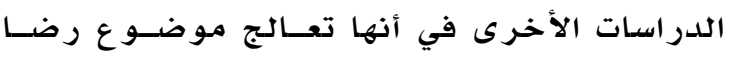

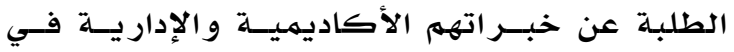

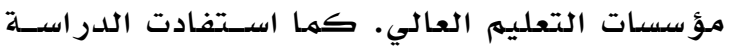

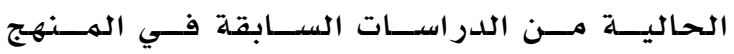

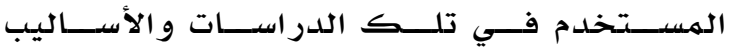

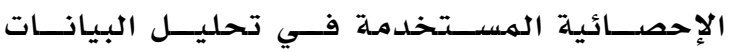

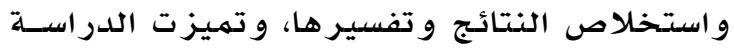

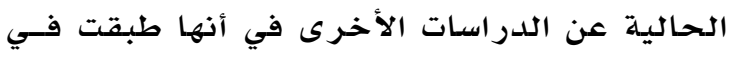

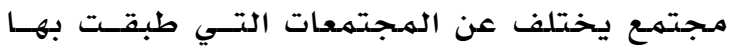

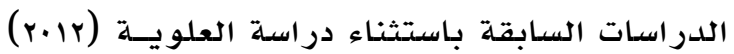

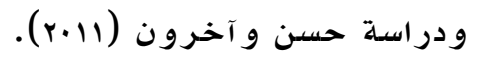

مشكلة الدراسة

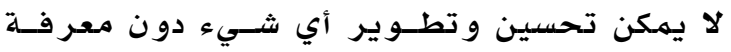
أهدافه أي لا بـ مـن معر فة رضـا الطالـب بـإدارة

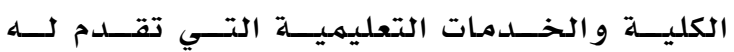
و الجوانب التدريسية التي يسعي إلى تحقيقها من

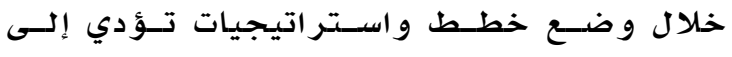
تحسين العملية التعليميسة وقيـاس جـودة الأداء.

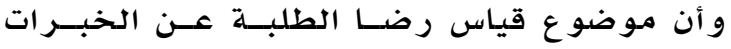

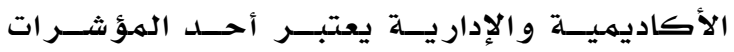
الههمــة لتقــويهم المؤسســة الأكاديميسة فـي أي

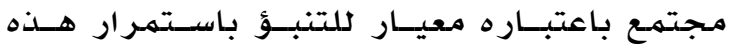
الهؤسسات الأكاديمية وبهما يحقق جودة التعلـيم و التي مـن أهدافها رضــا الطلبــة وتحسـين عمـل

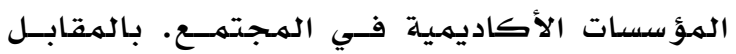
غيـاب رضــا الطلبــة يعنــي تــدني جــودة الأداء الأكاديمي و الإداري للمؤسسة الأكاديمية فشعور الطلاسب بالرضـا والارتيـاح عـن ذوعيــة الحيـاة

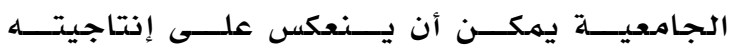

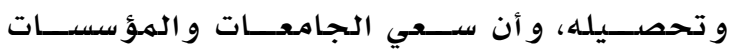
الأكاديمية لتقديهم خــدمات تعليهيـة ذات جـودة عالية سوف يسـاعد على تلبيــة حاجـات ورغبــات الطلبـة في تلك المؤسسات وسيعزز من العلاقــة

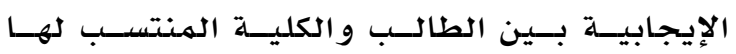
و يشـجعهم علـى زيـادة المعــارف و يتــيح لهـهم

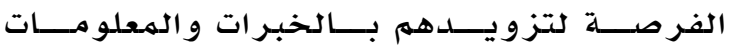

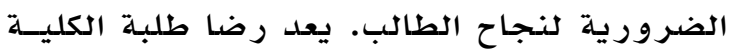
عن مستتوى الخبـرات الأكاديميـة والإداريــة التـي يعيشها الطالب داخل حر م الكلية مؤشـراً و اضـحاً
بالجامعة الهاشميلة عن الخبر ات و الخــدمات التـي قدمتها لهم الجامعة، في مجالات الخبر ات العامـة،

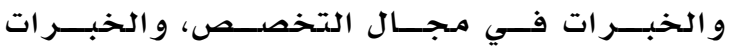

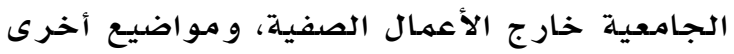
متعلقة بجامعتهم ودر استهمه، و مستقبلههم. استعهمل

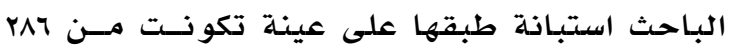

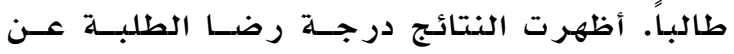

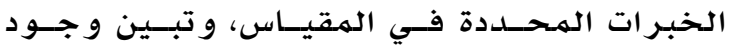
فروق ذات دلالة إحصائية عنــد مسـتوى الدلادـة

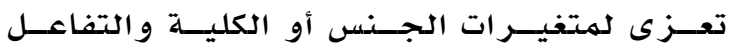

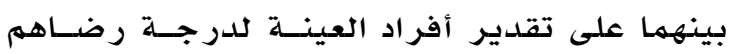

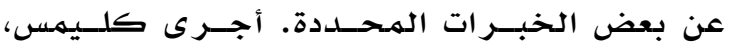

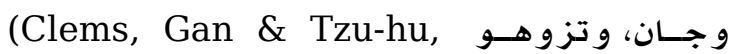

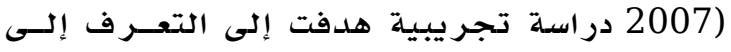

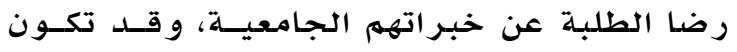

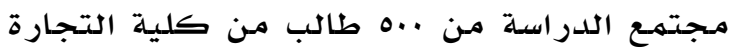
في جامعسة لينكـولن فـي نيوزيلنـــا فـي العـام

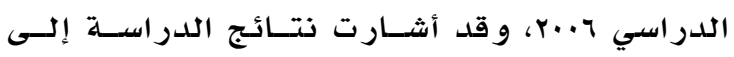
وجــود علاقــة إيجابيـة بـين رضـــا الطلبــة عـن

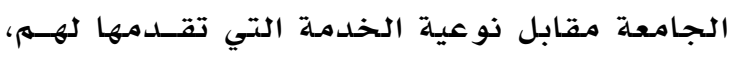
و عـدم وجـود علاقــة ذات دلالسـة إحصدـائية بـين الرسوم الجـامعيـة مقابـل نوعيـة الخدمـــة التــي

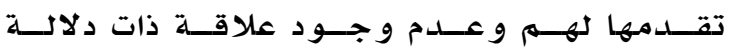
إحصائية بـين الرسـوم الجـامعيسة التـي يسدفعها

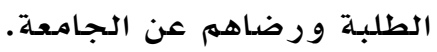

يتضـح مـن اسـتعر اض الدرراســات العربيــة منهــا

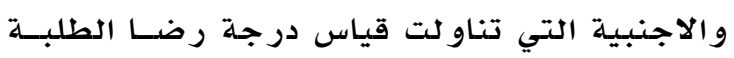
الجـامعيين عـن الخبـر ات الأكاديميـة و الإداريــة

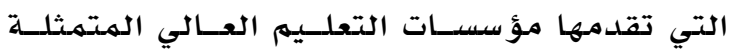

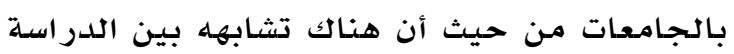

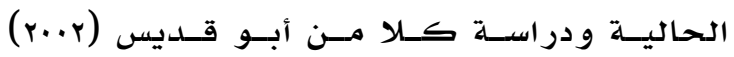

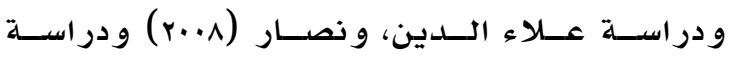

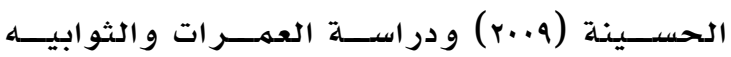

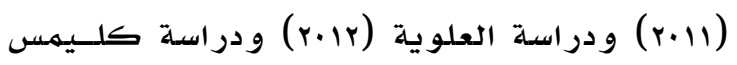

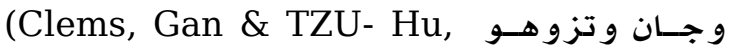
(2007 من حيث المتغير ات التي تناو لتها الدر اسـة

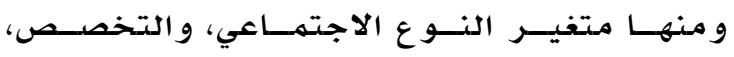

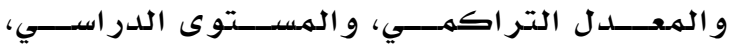
و اختلفت مـع الدر اسـات الســابقة مسـن حيـث عـدام

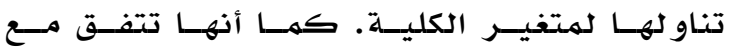


خبر اتهم الأكاديميلة والإدارية تعـزى إدىى

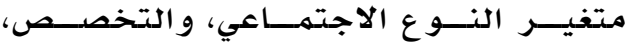

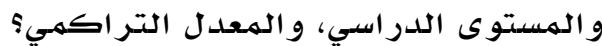

أهداف الدراسـة

\section{تتمثل أهداف الدراسة في الآتي:}

1. الكثف عن درجلة رضـا طلبة كلية العلــوم

التطبيقية بصحار عن خبر اتهم الأكاديمية درجة وهية

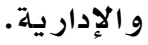

r. الكثــف عـن وجــود فــروق ذات دلالـــة

إحصائية عنــد مســتوى الدلالــة ه.ر • بـيـن

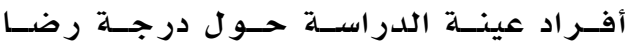
الطلبـة عن خبر اتهم الأكاديمية و الإداريسة

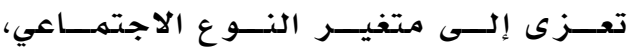

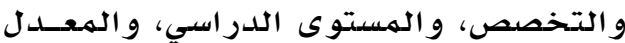

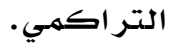

أهمية الدراسة

\section{تتمثل أهمية الدراسة في الآتي:}

تعدُ من المواضيع المهمـة المـرتبطة بجــودة التعليهم والتي تهلدف اليهـا كليـات العلــوم

التطبيقية بسلطنة عمان إلى تحقيقها. • إن دراسة رضا طلبة كلية العلوم التطبيقية بصحار عن خبراتهم الأكاديمية والإداريسة يبقى من الحـاجات الهـهمة لتقديه التوصيات

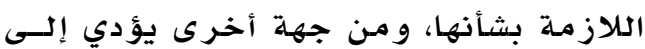
تزو يــد المســؤو لين الإداريـيـن فـي وزارة

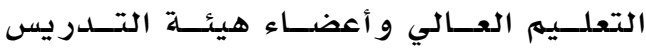
برؤية و اضحة عن درجة الرضا عـن تلــك واءك

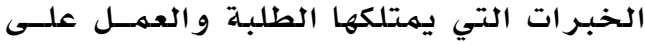
إشباع حاجاتهم المتنو عة .

\section{الطريقة وإجراءات الدر اسة}

\section{مجتمـع الدراسة وعينتها}

يتكون مـجتمـع الدراسـة من جميـع الطلبـة ذكـوراً

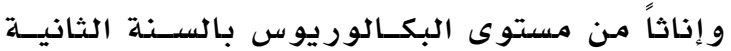
و الثالثة و المسجلين في كلية العلوم التطبيقيسة

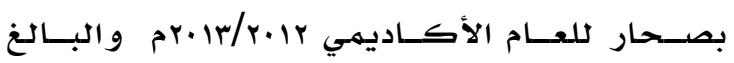

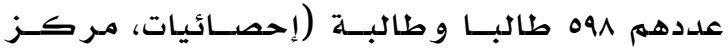
القبول و التسجيل بكلية العلوم التطبيقية بصحار،
على الاستجابة الفاعلة لتلبية احتياجـات الطلبـة المتنو عة و المتعددة و مقياسـا لكفاءة عمل الكلية. و نظراً لندرة وجود دراسات سـابقة فـي سـلطنة عمـان تقـيس مسـى رضــا الطلبـة عـن خبــر اتهم

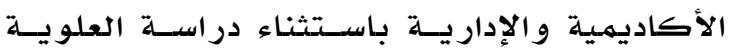

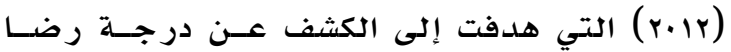

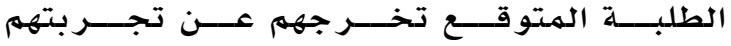
الأكاديمية في الجامعات الخاصـة بسلطنة عمـان،

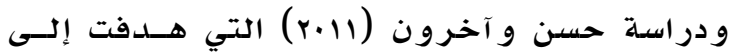

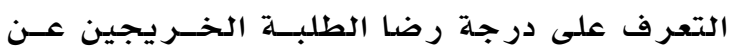

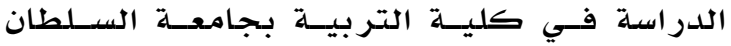
قابوس. و معظم الدر اسـات التي أجريت في سلطنه لئه

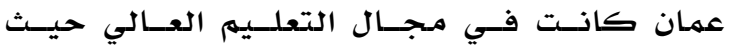

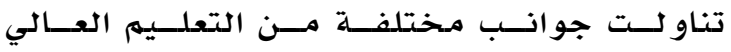

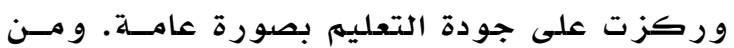

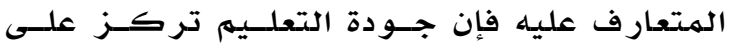
رضا الطلبـة عن مستوى الخــدمات التـي تقــدمها المؤسسـة الأكاديميسة. و بهــا أن الطلبـة يشـكلوا

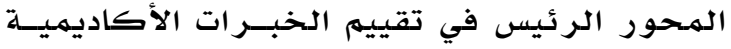

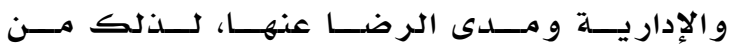
الضروري أخذ وجهات نظر هم.

و في ضدو ذلك تتحدد مشكلة الدر اسلة في تطبيق أداة لقيـاس درجــة رضــا الطلبــة عـن الخبــر ات الأكاديمية والإدارية في كلية العلوم التطبيقيسة دونة

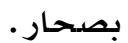

\section{أسئلة الدراسة}

ا. مــا درجــة رضــا طلبــة كليــة العلـــوم

التطبيقية بصحار عن خبراتهم الأكاديمية

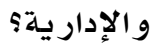

Y. با أهمية مجالات استبانة رضـا طلبة كلية العلوم التطبيقيسة بصـحـار عـن خبـر اتهم الأكاديميلة والإدار يلة r. ما درجة فاعلية فقرات أداة قيساس درجسـة رضا طلبة كلية العلوم التطبيقية بصدحار عن خبر اتهم الأكاديمية و الإدارية؟ ع. هل توجد فروق ذات دلالة إحصسائية عنــد

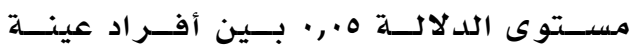
الدراسـة حول درجة رضا طلبة كلية عـن 
الحســينة، (r.a. (r.a) و در اســة عــلاء الــدين،

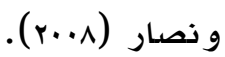

• الخطوة الخامسـة: تحكيم أداة الدراسـة من

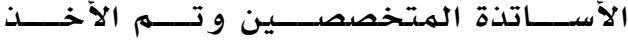

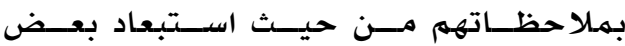
الفقر ات و إضافة فقر ات أخرى

• الخطوة السـادسة: تم احتسـاب معامل ثبـات

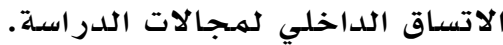

مصطلحات الدراسة

مفهوم الرضا: هو حالة الحس الشعوري البسيط

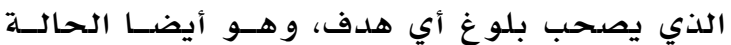
النهائية في الشعور التي تصاحب تحقيق دافع مـا لهدفه، كما أنه حالة مسرة ووهناء تالية للوصدول

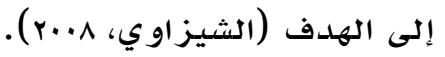

\section{قياس الرضا عن الخبرات الأكاديمية والإدارية} هو شعور داخلي لدى الطالب فـي كليـة العلــوم التطبيقيـة بصـحار يظهـره الطاسب مسن خـلالال تعبيره عـن مسـتوى رضـاه أو قبو ــهـ للخبـر ات الأكاديهية و الإداريسـة الــواردة فـي أداة الدر اســة

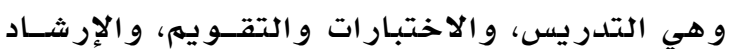
الأكسـاديمي، و الخــــمـات الأكاديميــة الهســـاندة

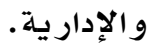

طالب الكلية: هو الطالب المسـجل للدراســة فـي مستوى البكالوريوس في كلية العلوم التطبيقية

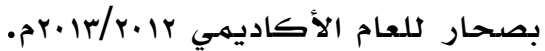

كلية العلوم التطبيقية بصحار: كليـة جامعيسة

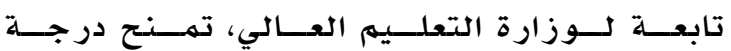
البكالوريوس فـي تخصصــات تقنيـة المعلومسات،

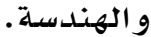

صدق أداة الدراسة وثباتها: للتحقق من صدلاحية

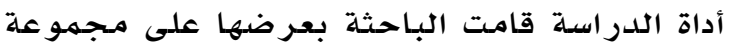

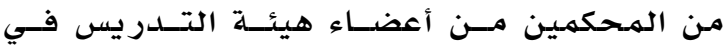
كلية العلوم التطبيقية بالرستاق، وطلسب مسنهم تحديل آرائهم من حيث الصياغة اللغوية للفقرات اتوليه و مناسبة الفقرات لهمجالاتها، و إضـافة أو تعديل أو

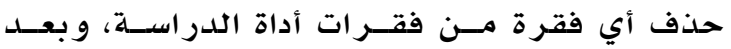
الأخذ بـآراء و مـلاحظــات المحكمهـين تـهم اعتمهـاد الفقرات التـي أجمــع المحكمسين علـى تعـديلها،

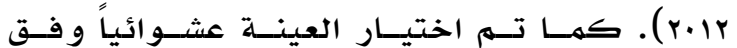
الطريقة العشوائية الطبقية العنقودية بحيث تـم

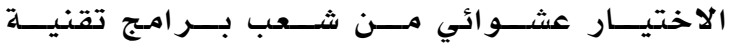

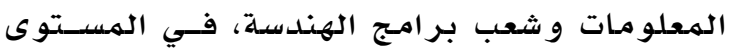
الثاني و الثالث و ذلك في الفصل الدر اسي الثـاني

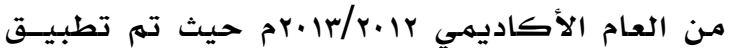
الأداة بصدورتها النهائية المؤلفــة مــن بــ فقــرة.

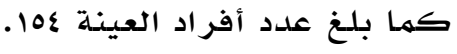

\section{منهج الدراسة}

اتبعت الباحثة المنهج الوصفي التحليلـي فـي

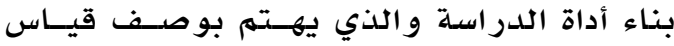
درجة رضا طلبة كلية العلوم التطبيقية عـن خبر اتهم الأكاديمية و الإدارية.

أداة الدراسة - (اسة

اعتمدت الباحثة في إعداد أداة الدراسة على الخططوات الآتية:

• الخطوة الأوولـى: تحلديـد أهــم الهـــالات

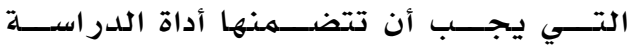
وتحديد مفهوم الرضا وقياس درجة الرضا

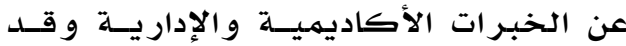

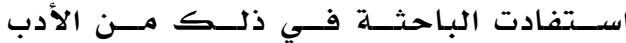

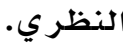

• الخطوة الثانية: المعلومات التـي حصدلت

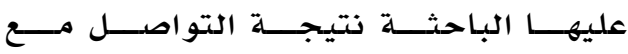
الأكـاديميين والأكــاديميين المســاندين و الإداريين بكلية العلوم التطبيقية بصحار . • الخطوة الثالثة: خبرة الباحثة في مجسال عملها واعتبار ها عضو هيئسة تـدريس فـي

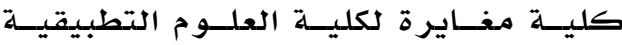

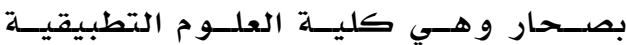
بالرستاق، وكـلا الكليتـين تتبعـان وزارة

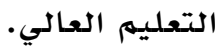

الخطــوة الر ابعسةة: كتابــة فقــر ات أداة الدرراسـة وذلك بالاستفادة مسـن الدراسـات

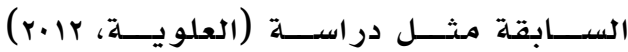

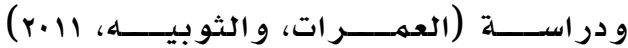

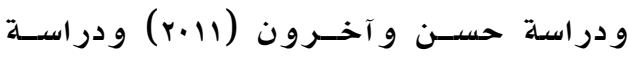


تـتلخص التحلـيلات فـي اسـتخر اج المتوســـات الحسابية، والانحر افات المعيارية لكل مجال مسن فئن

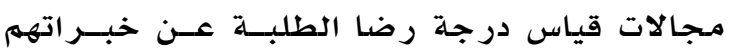

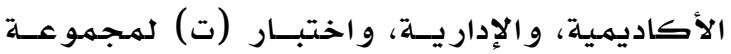
و احدة و لهـجموعتين مستقلتين، و تحليل التبـاين الأحادي، و اختبار شفيه لإيجاد دلالدة الفروق بـين المتو سطات الحسابية.

\section{نتائج الدراسة}

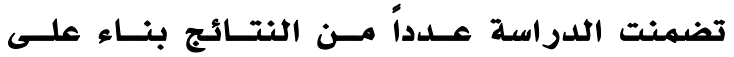
استجابات المستجيبين، وتمت مناقشة النتائج في ضوء الإطار النظري والدراسات السابقة، ومن ثم

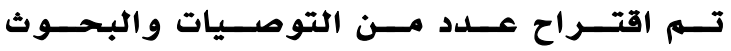
المستقبلية. عرض النتائج ذات الصلة بالسؤال الأول، والـذي ينص على ما يلي: ما درجة رضـا طلبـة كليـة

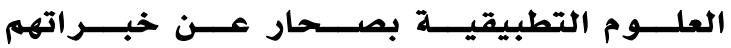
الأكاديمية والإدارية؟

للإجابة عن هذا السؤال، تم حسـاب المتوسط

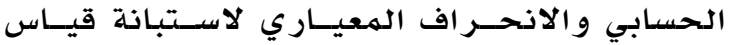
درجة رضا طلبة كلية العلوم التطبيقية بصسحار عن خبر اتهم الأكاديميسة و الإداريسة، و باسـتخدام

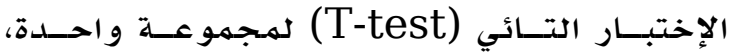
اتضح وجود دلالنة احصائية عنــد مسـتوى دلادسة

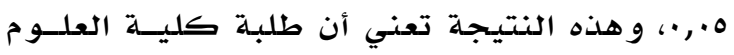

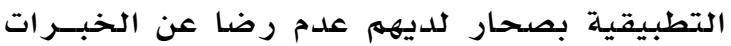

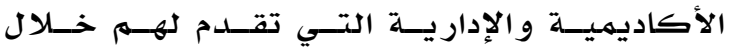

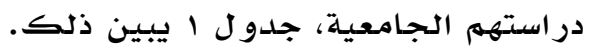

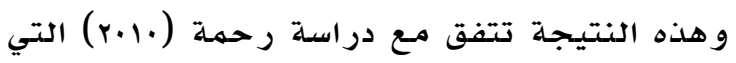

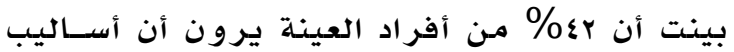

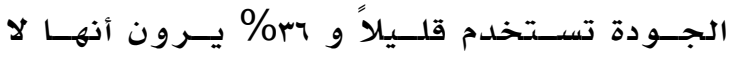

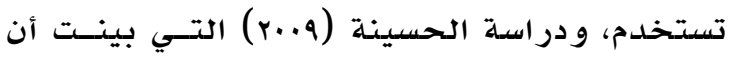
المستوى العام للمهجالات ضـعيف، ودراســة عـلاء

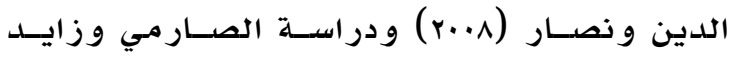

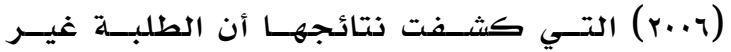
راضيين بلدرجة كافية عن الإثر اف الأكـاديهي.

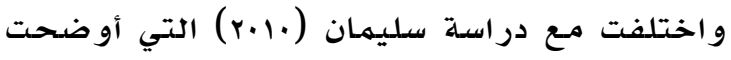

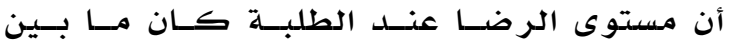

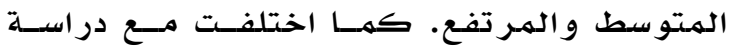

و ملاءمتهـــا، و بـــذلك أصــــحت أداة الدر اســـة بصور تها النهائية مكونة مــن بـ وهـي التـي تـمى

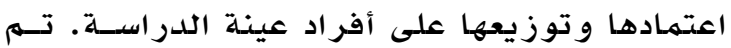
استخدام معادلة ألفا كرونباخ وذلك لاستخراج

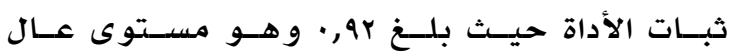

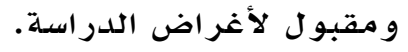
متغير ات الدر اسة

تضهمنت متغير ات الدراسـة نوعين من المتغير ات: اولاً: المتغيرات المستقلة، وشملت:

1. متغير الذوع الاجتماعي، وله فئتان (ذكر،

و أنثى)

r. متغيـر التخصـص ودهـه فئتـان (هندسـة،

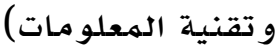

r. متغيــر المســتوى الدراســي، وولــه فئتحـان

(السنـة الثانية، السنة الثالثة)

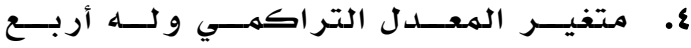

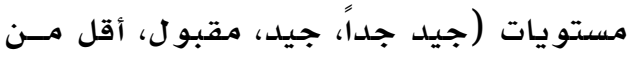

مقبو ل)

ثانياً المتغيرات التابعة وشملت قياس درجة رضا

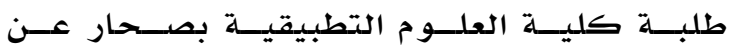
خبـر اتهم الأكاديميــة و الإدار يـهة و هــي خبــر ات

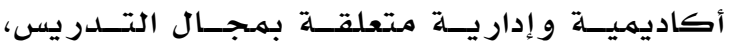

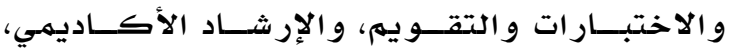
و الخدمات الأكاديمية المساندة و الإدارية.

إجر اءات تطبيق الأداة

بعد التحقـق مــن صــدق أداة الدراســة، وثباتهـا، و إخر اجها بصور تها النهائية تم توزيع الاسـتبانة على طلبة كلية العلوم التطبيقية بصحار باليسد عن طريق الباحثة ، وقد استغرقت عملية توزيـع

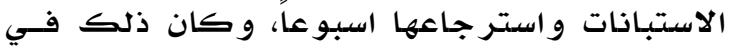
منتصف الفصل الدراسي الثاني للعام الأكـاديهي $\cdot r r+1 r / r+1 r$

\section{المعالجة الإحصائية}

تمت معالجة البيانات المستخلصدة مسـن الاسـتبانة

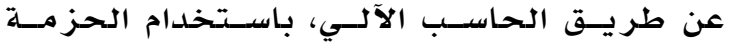

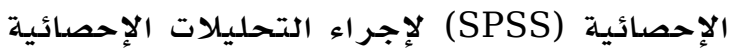

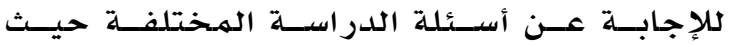


تقــويهم الطلبـــة وتقــويم العمليـــة التعليميـــة

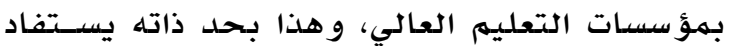
منـه في تأمين جودة التعليم. عرض النتائج ذات الصلة بالسؤال الثاني، والذي ينص على ما يلي: ما أهمية مـالات استبانة قياس درجة رضا طلبة كلية العلوم التطبيقية بصسحار عـن خبـراتهم

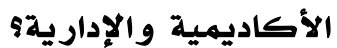

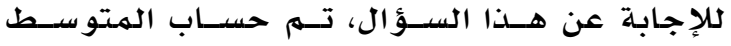

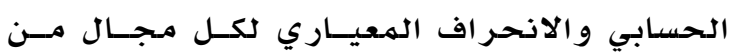

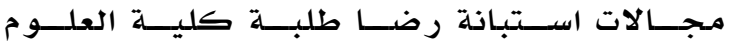
التطبيقيــة بصـحهار عـن خبــر اتهم الأكاديميــة

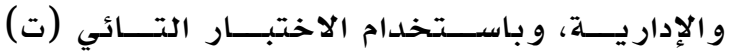

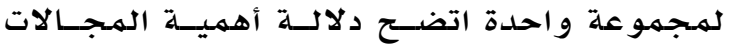

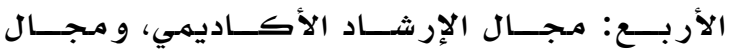

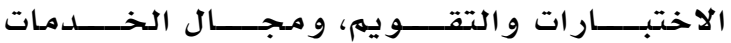

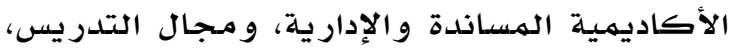

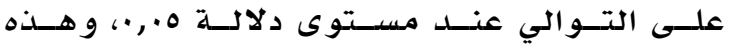
النتيجة تعني أن طلبة كليسة العلـوم التطبيقيسة بصحار يعيرون أهمية للمهجالات الأربع في درجة الهية رضاهم عن خبر اتهم الأكاديميلة والإداريسة التـي ير غبون في تحقيقها أثناء دراسـتهم فـي الكليـة، ونها، جدول r يبين ذلك.

يلاحظ مــن جــدول r أن المتوســات الحســابية

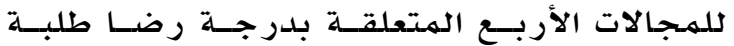

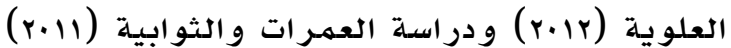

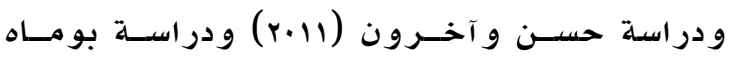
.(Boamah, 2009)

و تفسر الباحثة هذه النتيجة إلى وضوح الهقياس

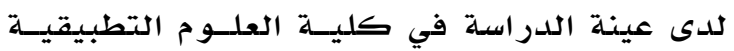
بصحار اتجاه رضـاهم عـن خبـر اتهم الأكاديميسة

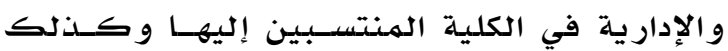
و عيهم بأهمية الدر اسـة داخـل الكليـة وقة وقناعـاتهم

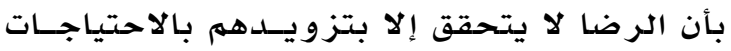
التي تحقق طموحاتهمه وتطلعاتهم إلى المسـتقبل

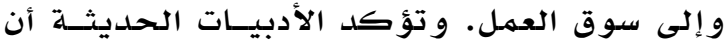

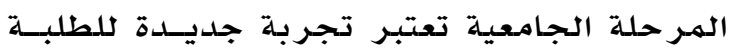
تختلف عن التجارب التعليمية ففيها الكثيـر مسن

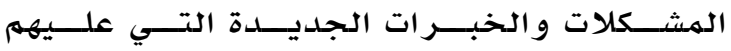
اجتيازها و مو اجهتها و التكيف معها مثـل التعــرف

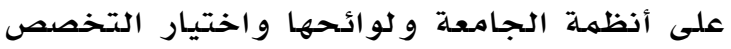
و التكيف معهل و الاختيار المهنــي و الإعـداد لمهنــة المستقبل و ما يرتبط ذلك من اتخاذ قرارات ذات

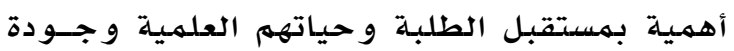

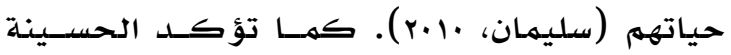

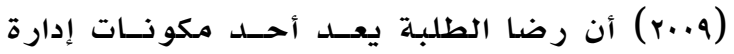

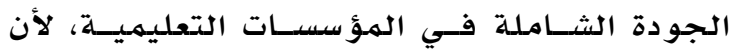
جوهر العملية التعليمية هي مساعدة الطلبـة على

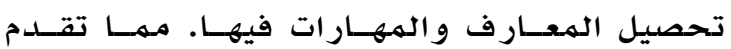

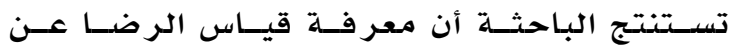
الخبرات الأكاديمية والإدارية للطلبة يساعد في احسي

جدول 1

نتائج اختبار (ت) لمجموعة واحدة لاستبانة قياس درجة رضا طلبة كلية العلوم التطبيقية بصدار عن خبراتهم الأكاديمية والإدارية

\begin{tabular}{|c|c|c|c|c|c|c|}
\hline \multirow{2}{*}{ الاحصائية } & \multirow{2}{*}{ قالمسوية (ت) } & \multicolumn{3}{|c|}{ مؤشرات العامل } & \multirow{2}{*}{ النظتوسط } & \multirow[b]{2}{*}{ 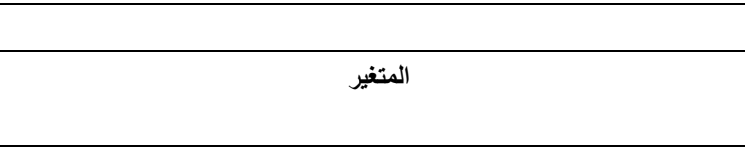 } \\
\hline & & الانحراف & الحسابي & الفقرات & & \\
\hline$\cdot, \cdots 1$ & $9, r r-$ & $r, r \cdot$ & $1 \cdot, r \varepsilon$ & $\varepsilon r$ & ir & قياس درجة رضا طلبة كلية العلوم التطبيقية بصحار عن خبراتهم الأكاديمية والإدارية \\
\hline
\end{tabular}

جدول r

نتائج اختبار (ت) لعينة واحدة لمعرفة دلالة مجالات قياس درجة رضا طلبة كلية العلوم التطبيقية بصحار عن خبراتهم الأكاديمية والإدارية مرتبة ترتيباً تنازلياً

\begin{tabular}{|c|c|c|c|c|c|c|}
\hline \multirow{4}{*}{ الاحصائية } & \multirow{4}{*}{ قالمحسة (ت) } & \multirow{2}{*}{\multicolumn{3}{|c|}{ مؤشرات العامل }} & \multirow{4}{*}{ النظويط } & \multirow{2}{*}{ مجالات استبانة قياس درجة رضا طلبة كلية العلوم التطبيقية بصحار عن خبراتهم } \\
\hline & & & & & & \\
\hline & & الانحراف & المتوسط & 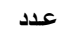 & & \\
\hline & & المعياري & الحسابي & الفقرات & & \\
\hline$\cdots \cdots$ & $\varepsilon, \uparrow_{\curlywedge}$ & $\cdot, \wedge \mathrm{V}$ & $r, 79$ & 1. & $r$ & مجال الإرشاد الأكاديمي \\
\hline$\cdots \cdots$ & $0, \Lambda \mathrm{r}$ & $\cdot, 7 \leqslant$ & $r, 79$ & 9 & $r$ & مجال الاختبارات والثقويم \\
\hline$\cdots \cdots$ & $\Lambda, \varepsilon r$ & $\cdot, 79$ & r,or & $1 \varepsilon$ & r & مجال الخدمات الأكاديمية المساندة والإدارية \\
\hline$\cdots \cdots$ & Ir,Ar & $00, \wedge \mathrm{V}$ & $r, \varepsilon r$ & 1. & $r$ & 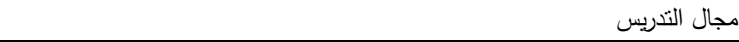 \\
\hline
\end{tabular}


عوامل تؤثر في مستوى الرضا عند الطلبـة منهــا

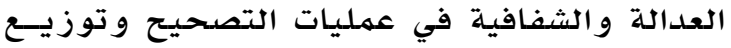

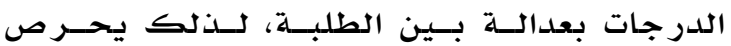
أعضاء هيئة التدريس وإدارة الكلية على توظيفها

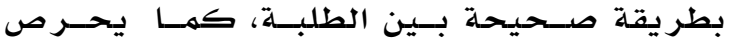
أعضــاء هيئــة التــدريس علــى مر اجعــة الأوراق الامتحانية مـع الطلبـة بعد الانتهـاء مسن عمليـات

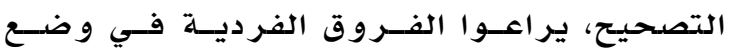
الأسئلة الامتحانية.

و جــاء مـجـال الخـــمات الأكاديميـة المســاندة والإدارية في المرتبة الثانية بمتوسط حسـابي بلغ

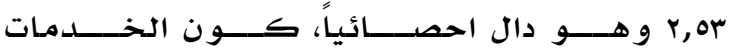
الأكاديمية المساندة والإدارية في تلــك الكليسة

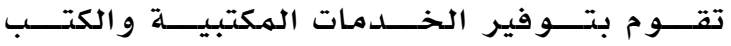

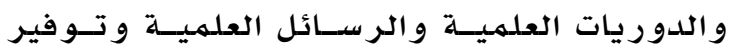
الأجهزة و الطابعات و غيرها التي تخدم الطلبة في تلك الكلية من خلال مركز مصنز مصادر التعلم، كما أن إدارة الكلية تعهل جاهدة على تـوفير الهنــاخ

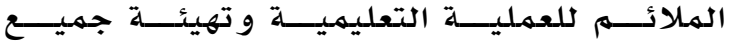

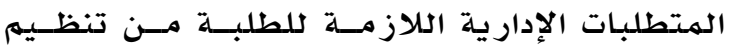
عملية التسجيل وتخصـيص أوقـات كافيـة لهـا،

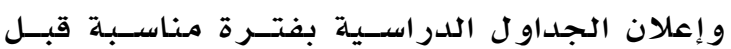
بداية العام الأكاديهي. و احتل مجال التدريس المرتبـة الاخيرة بمتوسط حسابي بلغ r\&, Y و هو دال احصائياً. ويهكن تعليل

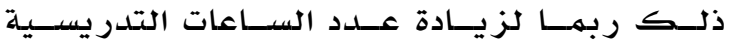
للأستاذ الجامعي في تلك الكلية، و تكليفه بأعمال

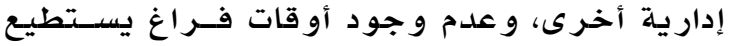

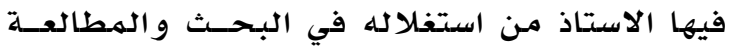
عن مستجدات العلهم والمعرفة أو ربما عدم و جود المد خطة فـي إدارة الكليـة عـن عقـــ دورات وورش

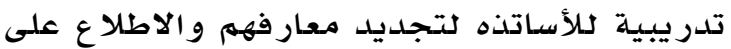
الجديد في مجال التدريس والطر ائق الحديثة.

عرض النتائج ذات الصلة بالسؤال الثالث، والذي ينص على ما يلي: ما درجة فاعلية فقـرات أداة قياس درجة رضا طلبة كلية العلوم التطبيقيـة بصحار عن خبراتهم الأكاديمية والإدارية؟ لغـرض الإجـابسة عـن هــذا الســؤال ومهن خـلال

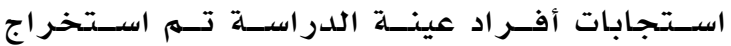

كلية العلوم التطبيقية عن خبراتهم الأكاديميـة

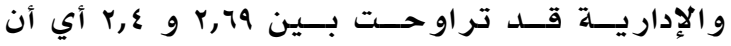

درجة الر ضا بالمستوى العام كانت متوسو سطة.

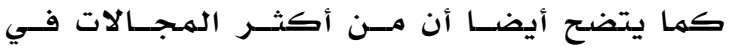

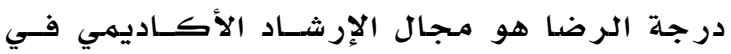
الهـرتبة الأولى حيث بلـغ المتوسط الحســابي لـهـ

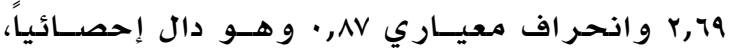

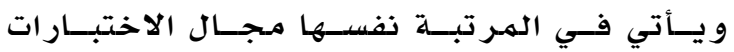

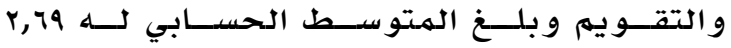

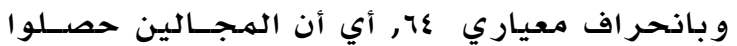
على نفس المتوسط الحسـابي مـع اختلاف بسـيط

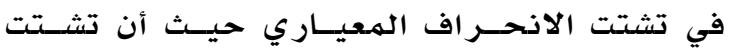

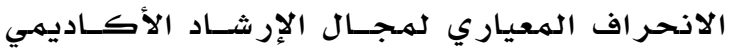

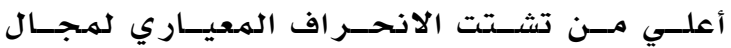

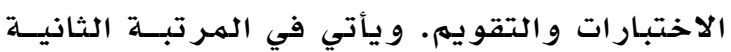
مجال الخدمات الأكاديميـة المســاندة و الإداريسة

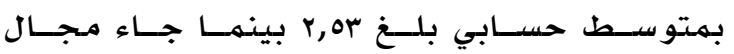
التدريس في الهـرتبة الثالثة بهتوسط حسابي بلغ $. r, \varepsilon r$

فبالنسبـة لمـال الإرثـاد الأكــاديمي فقـد احتـل

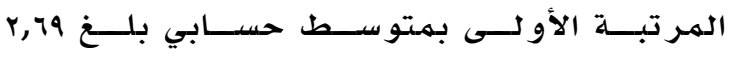

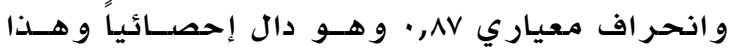

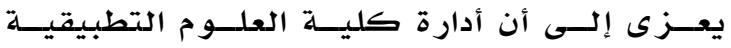

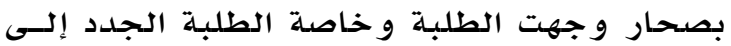
التعـريـف بأنظهــة الكليـة و لو ائحهــا و بر امجههـا و كيفية إرشادهم لعملية التسجيل حسب الخطط

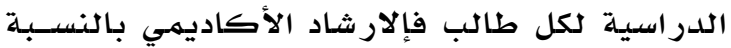
للطالب هو العمود الفقري لله داخل الكليـة فعــن

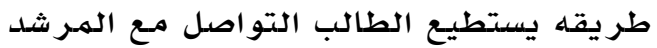
الأكاديهي الذي يستطيع أن يجيب عن تسـاؤلات

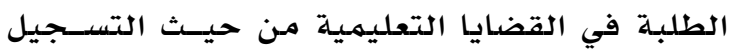

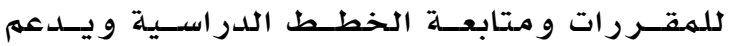
الطلبــة و يلبــي احتياجــاتهم الهـتعلقــة بـالبيئـــة

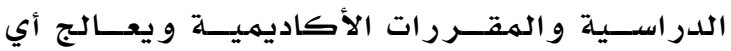
مشكلات تعتر ض الطالب أثناء مـرحلته الدراسية. أما فيما يتعلق بمجال الاختبارات والتقويم و الذي حصل على نفس مرتبة مجال الإرشاد الأكاديمي

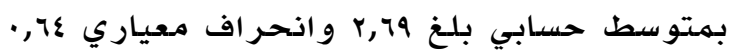
و هو دال إحصائيا، و تعلل الباحثة ذلك أن هنـالك 
المطروحة و قدمت بعض البرامـج التي استفاد منها الطلبـة في بداية كل عام أكاديمي. وحصلت الفقرة " يتعامل المرشد الأكاديمي مـع الطلبة بود واحترام" على الترتيب الثالث

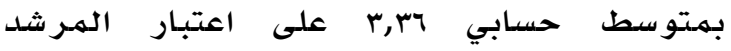
الأكاديمي حلقة الوصل بين الطالب وومركز القبول والتسجيل من حيث التسجيل للهقررات الدراسية ومساعدة الطالب على تخطي الصعو بات التي تواجهه أثناء الدرراسلة و منها الملاحظة الأكاديمية، لذلك يحر ئه المـرشد الأكاديمي كل الحرص على أقامـه التعاون والثقة المتبـادلة و الاحترام بينه وبين الطالب لأجل اكسـاب ود الكاب الطالب والرجوع إلى المرشد في أي وامدت وقد دون خوف أو تردد أو قلق من أي مقابلة يواجي اجهها

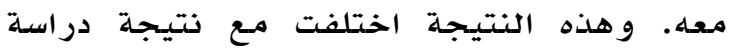

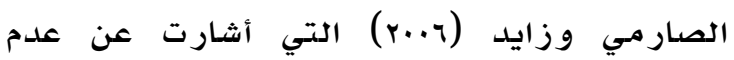
الرضا عن الإرشاد الأكاديمي في جامعة السلطان قابوس.

أما بالنسبة للفقرات الدنيا فقد احتلت الفقرة "يتوفر عدد كاف من أجهزة الكمبيوتر وخطوط الأنترنت في مركز مصادر التعلم" على الترتيب

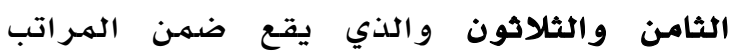

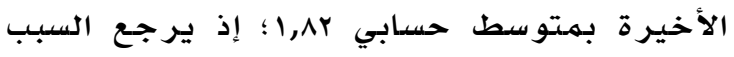
في ذلك أن توفير أجهزة حواسيب في مـركز

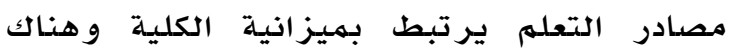

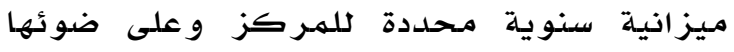

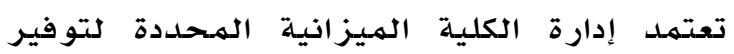

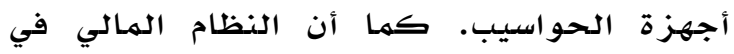
الكلية نظام مركزي مرتبط مباشرة آبرة بوزارة

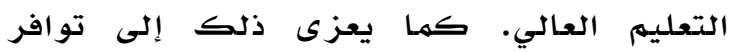

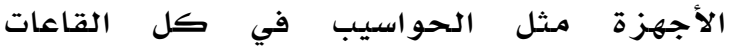

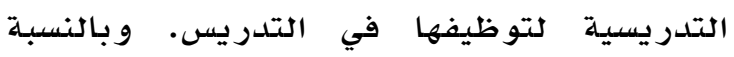
لخطوط الانتر نت قليلة في الهركز رئرئه ربها يعود إلى ضعف شبكة الانترنت بشكل عام وزيادة أعداد الدئل الطلبة السنوي الملتحقين بالكلية مها يؤدي إلى الضغط على استخدام الشبكة.

وتختلف هذه النتيجة مـع دراسة العلوية (r.r)

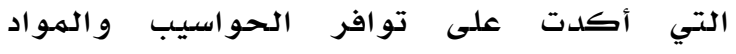
التعليمية بلدرجة متوسطة في الجامعات الخاصدة.

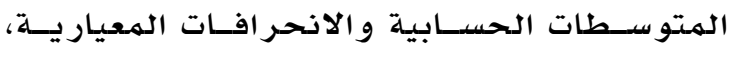
و تر تيب الفقرات من أعلى متوسط حسـابي إلـى أسى

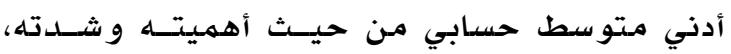
و كما هو موضح في جدول مل م.

يتضح من نتائج جدول r م أن هناك فقر ات حصدات

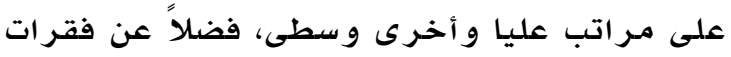
احتلت مـر اتب دنيا مـن حيث متوسطاتها الحسابية، و قد ارتأت الباحثة أن تفسر بعض احض الفقرات البيت العليا و الدنيا لتوضح مدى أهميتها في إستبانة قياس درجة الرضا عن الخبرات الأكاديمية والإدارية

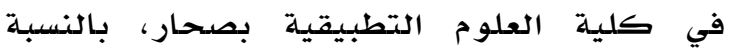
للفقرات العليا تبين أن الفقرة تسير عملية

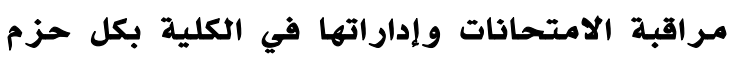
و التي كان تسلسلها 10 في الأداة حيث احتلت

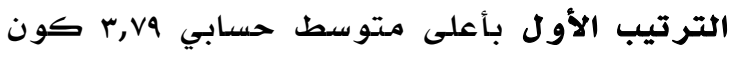
إدارة الكلية تحرص على تهيئة المناخ الملائم الهم

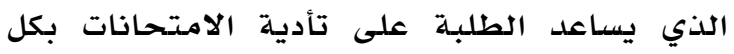

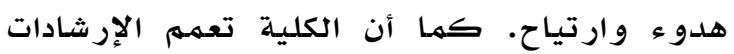

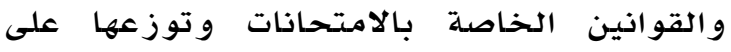
الطلبة وعلى أعضاء الهيئة التدريسية قبل البداء البهاء بعقد الامتحانات بفترة كافية، ويكون مركز

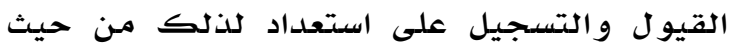

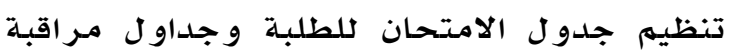
أعضاء الهيئة التدريسه للقاعات الامتحانية.

وحصلت الفقرة "تشرح العمادة أنظمة الكلية

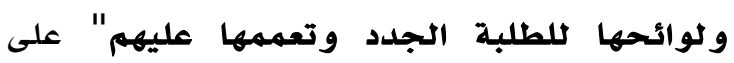
الترتيب الثاني بمتوسط حسابي جورب كون إدارة

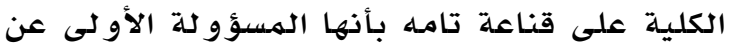
تعريف الطلبة بأنظمة الكلية ولوائحها للطلبة الجدد وتقوم بذلك في الاسبوع التعريفي للطلبـة الجدد في بداية كل عام أكاديهي ووذلك

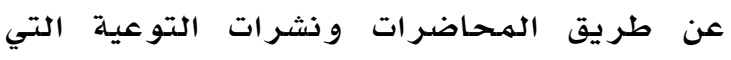

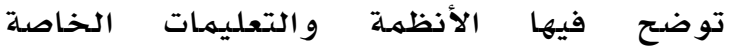

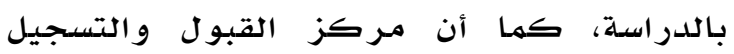
يقوم بتوزيع الكتيب الخاص بالنظام الأكاديمي لكليات العلوم التطبيقية. وهذه بود النتيجة اتفقت

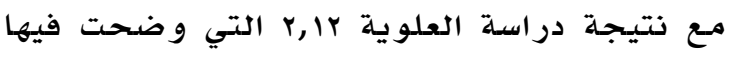
أن الجامعات الخاصدة بالسلطنة وجهت الطلبة

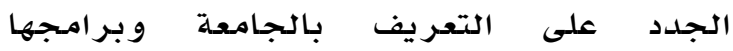


عرض النتائج ذات الصلة بالسؤال الرابع، والذي

\section{ينه على ما يلي:}

ما الفروق ذات دلالة إحصائية عند مستوى دلادسة

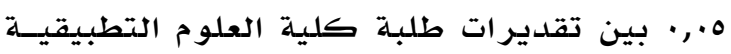

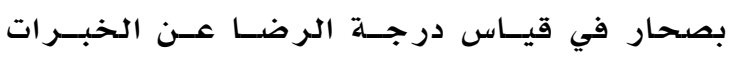

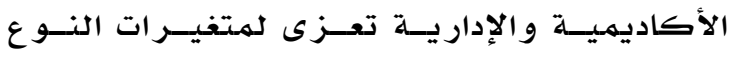

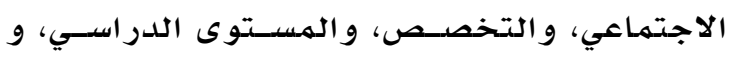
المعدل التهم اعي، والكمي.

T-) للإجابة عن هذا السؤال تم إسـتخدام اختبـار

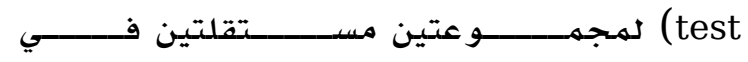

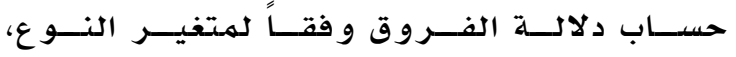

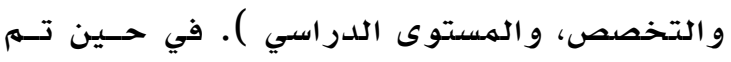

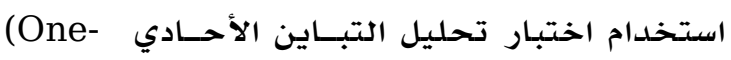

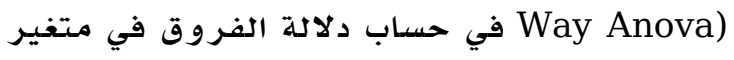

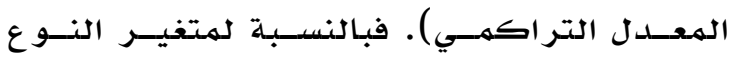

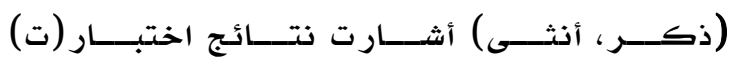

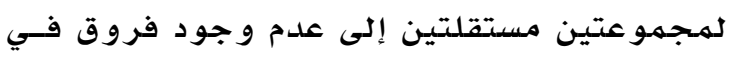
استبانة قياس درجــة رضـا طلبــة كليــة العلــوم

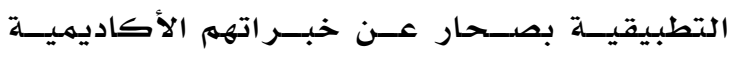

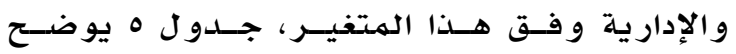
ذلك.
كما جاءت الفقرة "توفر الكلية مواقف مناسبة

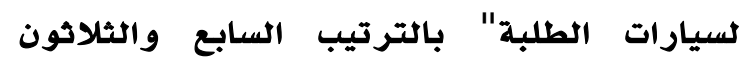

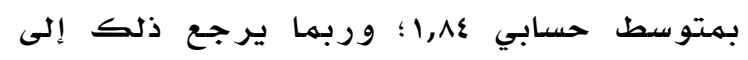

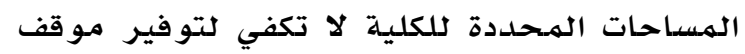

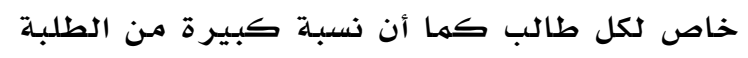

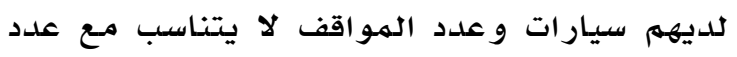
الطلبة. واختلفت هذه النتيجـة مـع نتيجة علاء

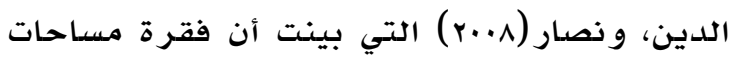

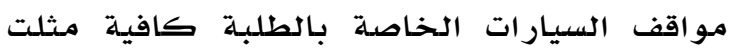

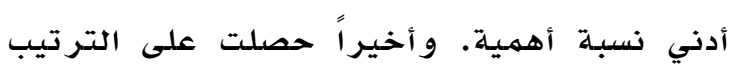

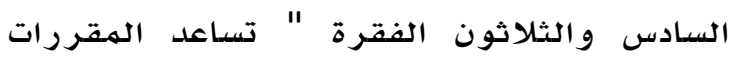

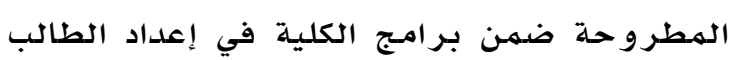
للعمل المستقبلي" بمتوسط حسـابي الباحثة ذلك لقلة الدورات التدريبية التي تعطى الدي

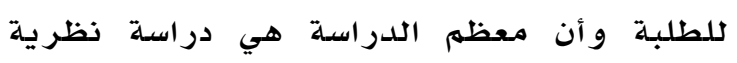
باستثناء بعض المقررات يوجد بها تدريب ووهي

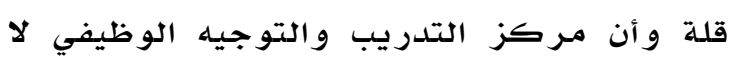

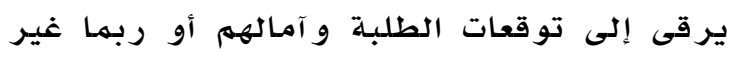

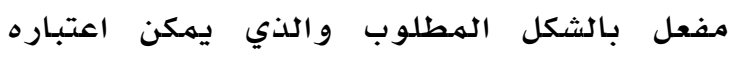
الجهة المسؤولة عن متابعة الخريجين الهين وتقديه

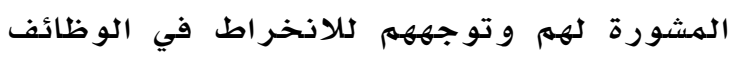

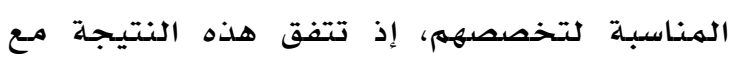

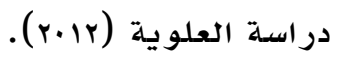
كما تم الإجابة على السؤال الثالث مـن خلال إيجاد قيم معاملات الارتباط بين الإجاه الأبعاد التي

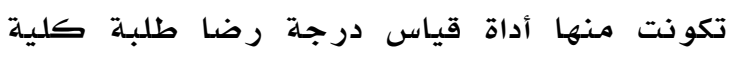

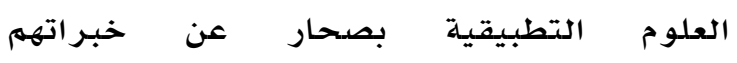
الأكاديمية و الإدارية وكيفية ارتباطية إطها معاً من

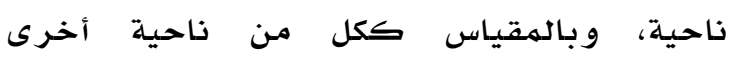
باستخدام معاملات ارتباط بيرسون ونسياس كما يبين في

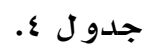

يلاحظ من جدول \& أن معاملات الارتباط بين

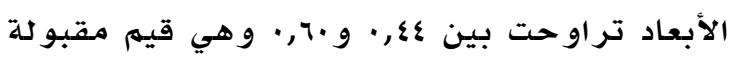

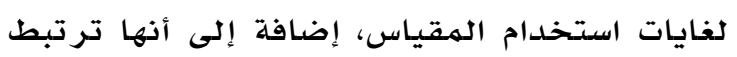

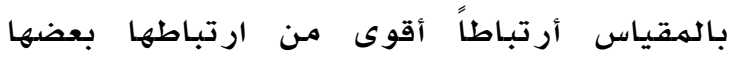

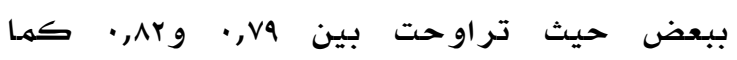

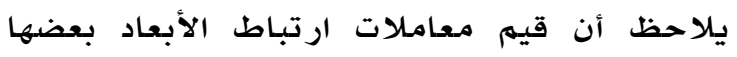

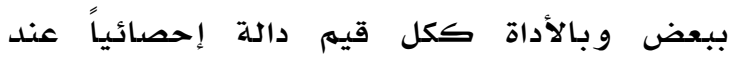
مستوى الدلادلة ه. 
جدول (r)

فقرات استبانة قياس درجة رضا طلبة كلية العلوم التطبيقية بصحار عن خبراتهم الأكاديمية والإدارية مرتبة ترتيباً تنازلياً حسب اوساطها الحسابية

\begin{tabular}{|c|c|c|c|c|c|}
\hline الترتيب & الانحراف المعياري & المسابي & 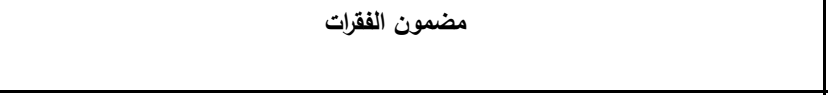 & فيلسل الفقرة & $ت$ \\
\hline 1 & $1,1 \varepsilon$ & $r, v q$ & | تسير عملية مراقبة الامتحانات وإداراتها في الكلية بكل حزم & 10 & 1 \\
\hline r & $1,1 \pi$ & $r, \leqslant \uparrow$ & |تشرح العمادة أنظمة الكلية ولوائحها للطلبة الجدد وتعمها عليهم & זr & r \\
\hline r & l,r. & $r, r$ & | يتعامل المرشد الأكاديمي مع الطلبة بود واحترام & rr & $r$ \\
\hline$\varepsilon$ & 1,19 & $r, r \varepsilon$ & | تقدم الكلية برنامجاً توجيهياً وإرشادياً للطلبة المسجلين & ro & $\varepsilon$ \\
\hline$\circ$ & $\cdot, 9 \mathrm{~V}$ & $r, 17$ & | يعطي الأساتذة فكرة واضحة عن أهداف المقرر الذي يدرسه في الأسبوع الأول من الفصل الدراسي & 1 & 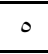 \\
\hline 1 & 1,10 & $r, 11$ & | يحدد الأساتذة المراجع والكتب المقررة المناسبة للمقرر الدراسي & $\circ$ & 1 \\
\hline $\mathrm{v}$ & 1,11 & $r, \cdot \Lambda$ & تحرص الكلية على إقامة ملتقيات طلبتية بين كليات العلوم التطبيقية & $\varepsilon r$ & $v$ \\
\hline$\wedge$ & 1,49 & $r, .0$ & | يحدد أساتذة الكلية مواعبد الامتحانات بالإتفاق مع الطلبة & ir & $\wedge$ \\
\hline 9 & 1,19 & r,१५ & | تتمتع مرافق الكلية بالنظام والمظهر الجيد & $\varepsilon$ & 9 \\
\hline 1. & 1,19 & r,qr & تدعم عمادة الكلية الأنثطة الطلبتية وتبرز مواهب الطلبة في الأنشطة & ro & 1. \\
\hline 11 & 1,19 & $r, \wedge V$ & | يوجد دليل خاص لضوابط الامتحانات في الكلية & ir & 11 \\
\hline ir & 1,19 & $r, \wedge T$ & | يوفر مركز التعلم المراجع العلمية المفيدة للمقررات الدراسية & rr & ir \\
\hline 14 & $1, \cdot 1$ & $r, \wedge$ & | يتتاسب عدد الطلبة مع المرشد الأكاديمي & ru & 14 \\
\hline $1 \varepsilon$ & $1, Y 4$ & $r, 79$ & | يُعطى الطلبة الفرصة للمناقشة في الإجابة عن أسئلة الاختبارات & 19 & $1 \varepsilon$ \\
\hline 10 & 1,01 & $r, 74$ & | يؤثر الإرشاد الأكاديمي في رفع المعدل التزاكمي للطالب وخفضه & rV & 10 \\
\hline 17 & $1, r r$ & r,70 & تتعاون إدارة الكلية مع مركز القبول والتسجيل في تسجيل المواد التي يحتاجها الطالب & r & 17 \\
\hline iv & 1,19 & r, tr & يخصص المرشد الأكاديمي وقتاً كافياً للإرشاد الأكاديمي & rt & iv \\
\hline 11 & $1, r r$ & $r, 01$ & | تساعد التوجيهات المرشد الأكاديمي في تحديد الخطة الدراسية للطالب & r4 & 11 \\
\hline 19 & 1,r & r,07 & | يلتزم المرشد الأكاديمي بالساعات المكتية التي يحددها لمراجعة طلبةه & ri & 19 \\
\hline r. & $1, r V$ & r,or & | بساعد المرشد الأكاديمي الطلبة في اختيار المقررات الدراسية المناسبة لكل فصل دراسي & $r \varepsilon$ & r. \\
\hline r) & $1, r$ r & $r, 01$ & تسعى عمادة الكلية إلى إيجاد حلول للمشكلات التي تواجه الطلبة أثناء تسجيل المقررات & r. & r) \\
\hline rr & $\cdot, 94$ & r,o. & | يستخدم اساتذة الكلية أساليب تقويم منتوعة & $1 \varepsilon$ & rr \\
\hline rt & $1, .0$ & r,o. & | يتسم الأساتذة بالموضوعية في طريقة تصحيح الاختبارات والواجبات & iv & $r$ \\
\hline r & $1, .0$ & $r, \varepsilon \varepsilon$ & |نساعد المقررات الدراسية في التخصص على مواكبة المستجدات العلمية في مجال التخصص & 1 & $r \varepsilon$ \\
\hline$r \varepsilon$ & $1, r \cdot$ & $r, \varepsilon r$ & | يساعد المرثد الأكاديمي الطلبة أثناء عمليات تشجيل المقرات & r. & ro \\
\hline$r \varepsilon$ & $1, .0$ & $r, \varepsilon r$ & | يقدم الأساتذة التغذية الراجعة للطلبة بعد الانتهاء من تصحيح الامنحانات & 11 & rt \\
\hline ro & $\cdot, 9 \leqslant$ & $r, r v$ & | تتلاعم أساليب الثقويم في الكلية وطبيعة أساليب التنريس المستخدمة & 11 & rV \\
\hline r4 & 1,10 & $r, r \leq$ & | توفر الكلية فصولاً دراسية ذات تصميم مناسب للمحاضرات & $\varepsilon r$ & rA \\
\hline tr & $1, r$ & r,rr & |تقدم الكلية المكافآت الطلبةية بصورة منتظمة & $r v$ & rq \\
\hline rs & 1,14 & r, rr & |تشجع إدارة الكلية الطلبة لحضور ندوات أو مؤتمرات سواء داخل السلطنة أم خارجها & rq & $r$. \\
\hline rA & 1,11 & r,ret & | يتمتع أساتذة الكلية بالكفاءه والتميز في التنريس & 9 & M \\
\hline rq & $1, .0$ & $r, r V$ & | يوظف أساتذة الكلية تقنيات تعليمية متتوعة في التنريس & $r$ & rt \\
\hline$r \cdot$ & 1,11 & $r, r_{1}$ & | تقيم الكلية حوارات نقاشية تعليمية بصورة منتظمة & ra & rt \\
\hline r & $\cdot, 97$ & $r, I V$ & | يطور الأساتنة المحاضرات التصريسية عن طريق التغذية الراجعة الواردة من الطلبة & $\wedge$ & $r \varepsilon$ \\
\hline rt & $1, \cdot r$ & $r, 10$ & | يبتعد الأساتذة عن أساليب الحفظ والتلقين في التدريس & r & ro \\
\hline r & $1,1 \mathrm{~V}$ & $r, 1 \leq$ & توفر عمادة الكلية قنوات اتصال ليتككن الطالب من خلالها التعبير عن شكوى أو مشكله قد تواجهه & $r$ & r4 \\
\hline$r \varepsilon$ & $\cdot, 97$ & $r, \cdot \Lambda$ & | يراعي اساتذة الكلية الفروق الفردية بين الطلبة في عملية أساليب التقويم المستخدمة & 17 & rv \\
\hline$r \varepsilon$ & $1, r$ & $r, \cdot \Lambda$ & | تشجع أساليب التدريس المستخدمة على التعلم الذاتي & v & rᄉ \\
\hline ro & 1,11 & $r, \cdot r$ & | يتابع المرشد الأكاديمي مشكلات الطلبة الأكاديمية & rq & rq \\
\hline r4 & $\cdot, 94$ & $1,9 \mathrm{~V}$ & | تساعد المقررات المطروحة ضمن برامج الكلية في إعداد الطالب للعمل المستقبلي & $\varepsilon$ & $\varepsilon \cdot$ \\
\hline re & $\cdot, \wedge \Lambda$ & $1, \wedge \varepsilon$ & | يقام الأساتذة المادة العلمية بدقة وبصورة مشوقه وجذابه. & 1. & « \\
\hline tr & $1, \cdot r$ & $1, \wedge \varepsilon$ & | توفر الكلية مواقف مناسبة لسيارات الطلبة & $\varepsilon$. & $\varepsilon r$ \\
\hline ru & $1, \cdot r$ & $1, \lambda r$ & ليتوفر عدد كافٍ من أجهزة الكمبيوتر وخطوط الانترنت في مركز مصادر التعلم & $r \varepsilon$ & $\varepsilon r$ \\
\hline
\end{tabular}


رضاهم. و اختلفت مـع دراسـة أبوقـديس (r...r)

و در اسـة (Chen \& Hughes, 2004).

و بالنسـبـة لمتغيـر التخصـص (هندســة ، تقنيـة

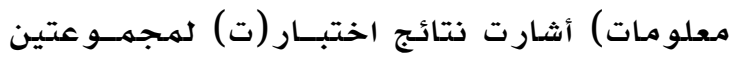

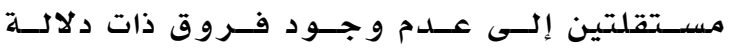
إحصائية في اسـتبـانة قيـاس درجسـة رضــا طلبــة كلية العلوم التطبيقيـة بصـحـار عـن خبـراتهم الأكاديمية والإدارية وفق هذا المتغير ، جـدول يوضتح ذلك.

وربهـا يعزى ذلك إلى أن الظروف التي يعيثـها طلبـة الهندسـة هي نفسها التي يعيشها طلبـة تقنية

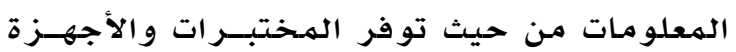
و الوسائل التعليمية المعينـة على التعليه و تـوفير الكادر التدريسـي المناسـب لهـذين التخصصسين.

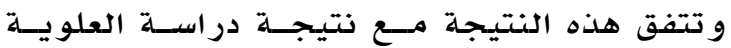

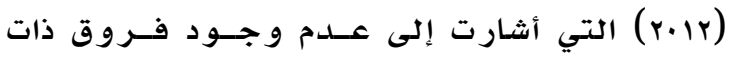
دلالة احصائية في متغير التخصسص عـدا مـجـال

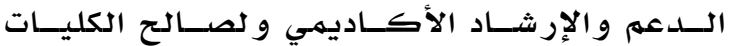

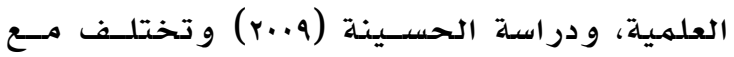

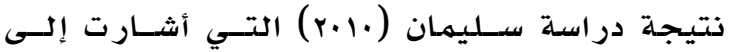

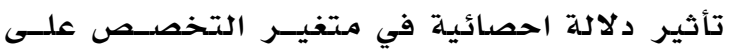
جميع الأبعاد باستثناء إدارة الوقته

جدول (0)

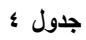

معاملات الارتباط بين أبعاد الأداة ودرجتها الكلية

\begin{tabular}{|c|c|c|c|c|}
\hline الكلي & الألألاديمية & الأكاديمي & والالتقويم & المجالات \\
\hline $\begin{array}{l}*, Y Y \\
* \cdot, \wedge r \\
* \cdot, Y q \\
* \cdot, Y q\end{array}$ & 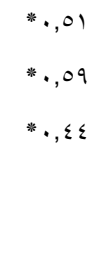 & $\begin{array}{l}*, \leqslant 0 \\
* \cdot, \leqslant V\end{array}$ & $* \cdot, \uparrow$ & 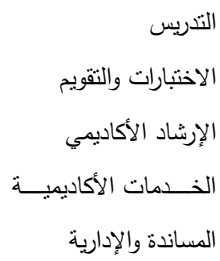 \\
\hline
\end{tabular}

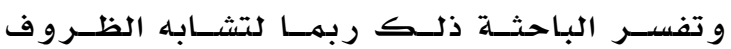
و الإمكانـات بــين الجنســين فـي كليــة العلــوم التطبيقية بصدار وتوزيـع الخــدمات بالتســاوي

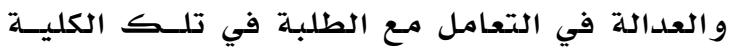

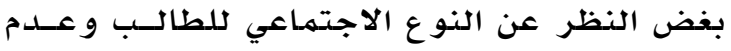

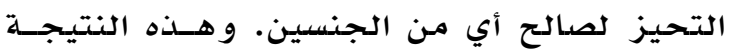

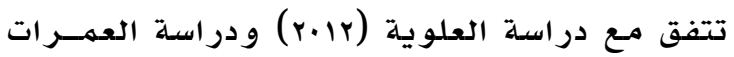

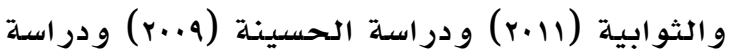

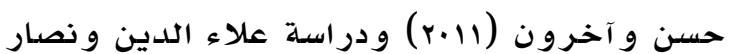

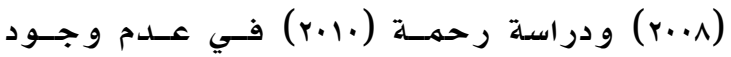
فروق بين الذكور والأنساث فـي تقـدير درجسـة

\begin{tabular}{|c|c|c|c|c|c|c|c|c|}
\hline \multirow{3}{*}{ الإحصائية } & \multirow{3}{*}{ الحرية } & قيمة (ف) & \multirow{2}{*}{ قيمة (ت) } & \multicolumn{2}{|c|}{ الأناث (ن = (a) } & \multicolumn{2}{|c|}{ الذكور (ن = ri) } & \multirow{3}{*}{ المتغير النوع } \\
\hline & & & & الانحراف & المتوسط & الإنحراف المعياري & المتوسط & \\
\hline & & $\ldots 0$ & $\ldots 0$ & المعياري & الحسابي & & الحسابي & \\
\hline \multirow[t]{3}{*}{$\cdots 9 r$} & lor & r,AV & 1,11 & r, ro & $1 ., 0.0$ & 1,97 & $1 \cdot, 1 \cdot r$ & قياس درجة رضا طلبة كلية \\
\hline & & & & & & & & العلوم التطبيقية بصحار عن \\
\hline & & & & & & & & خبراتهم الأكاديمية والإدارية \\
\hline
\end{tabular}

جدول (

نتائج اختبار (ت) لدلالة متغير التخصص في استبانة قياس درجة رضا طلبة كلية العلوم التطبيقية عن الخبرات الأكاديمية والإدارية

\begin{tabular}{|c|c|c|c|c|c|c|c|c|}
\hline \multirow[t]{3}{*}{ الالالة الإحصائية } & \multirow[t]{3}{*}{ درجة الحرية } & \multirow[t]{3}{*}{ قيمة (ف) } & \multirow[t]{3}{*}{ قيمة (ت) } & \multicolumn{2}{|c|}{ تقنية المعلومات } & \multicolumn{2}{|c|}{ الهنسة } & \multirow{3}{*}{ التخصص } \\
\hline & & & & الانحراف & المتوسط & الإنحراف & المتوسط & \\
\hline & & & & المعياري & الحسابي & المعياري & الحسابي & \\
\hline \multirow[t]{3}{*}{$\cdot, 10$} & $10 r$ & ., & $\cdot, 9 \mathrm{~V}$ & r, ro & $1 \cdot, I V$ & $r, 1 \leq$ & $1 \cdot, 0$ r & قياس درجة رضا طلبة كلية \\
\hline & & & & & & & & العلوم النطبيقية بصحار عن \\
\hline & & & & & & & & خبراتهم الأكاديمية والإدارية \\
\hline
\end{tabular}


جدول

نتائج اختبار (ت) لالالة متغير المستوى الدراسي في استبانة قياس درجة رضا طلبة كلية العلوم التطبيقية بصحار عن خبراتهم الأكاديمية والإدارية

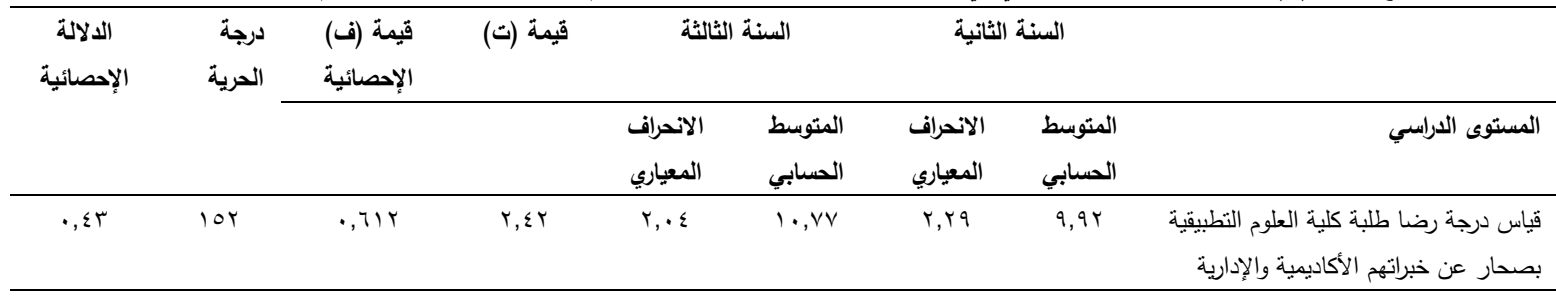

جدول (^)

نتائج تحليل التباين الاحادي لدلالة متغير المعل التراكمي في استبانة قياس درجة رضا طلبة كلية العلوم التطبيقية بصحار عن خبراتهم الأكاديمية والإدارية

\begin{tabular}{|c|c|c|c|c|c|c|}
\hline الدلالة & قيمة (ف) & متوسط المربعات & درجة الحرية & مجموع المربعات & مصدر التباين & المتغير المعدل التراكمي \\
\hline \multirow{3}{*}{$\cdot, \cdots$} & \multirow{3}{*}{$V, 09 V$} & Tr,VYT & $r$ & $9 \wedge, 19 \wedge$ & بين المجموعات & قياس درجة رضا طلبة كلية العلوم التطبيقية \\
\hline & & $\varepsilon, r \cdot q$ & 10. & $7 \leq 4, r q 1$ & ضمن المجموعات & \\
\hline & & & lor & $V \leq \varepsilon, \leqslant 9$ & المجموع & \\
\hline
\end{tabular}

لأن هناك ضوابط و لوائح يحددها مركز القبول

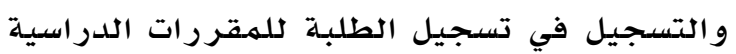
و التي ترتبط بمدى حصول الطالب على المعسدل الهـرتفع وهو الشرط الأسـاسي فـي عـدـد ســاعات

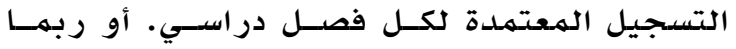
ينظر الطلبـة في حالــة حصدولهم علـى المعـدل

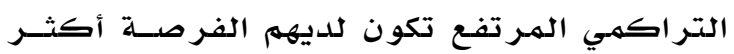
مـكنـه لاستكمال دراستهم العليـا فـي المســتقبل. كما تفسر الباحثة ذلك إلى أن التحـاق الطلبــة

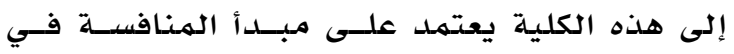
حصول الطلبـة علـى معسدلات عاليـة فـي ثـهادة

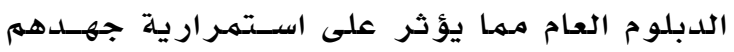
أثناء الدر اسـة الجـامعيلة.

\section{التوصيات}

ا- قيام وزارة التعلـيهم العـالي، و الهـديريـة

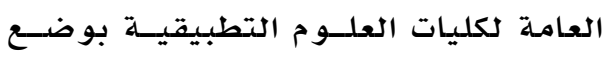

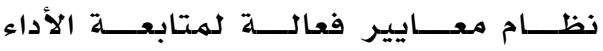
الأكاديمي والإداري للكليـات و أن يكسون

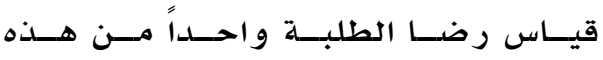
المعايير

r- ضرورة اهتمـام كلية العلــوم التطبيقيـة بصـحار عينــة الدراســة بتحقيسق رضـا

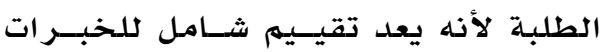

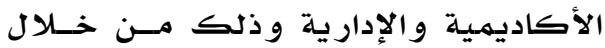

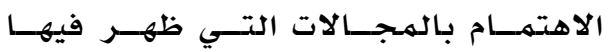

أما مـا يخص متغير المستوى الدراسي (السنة

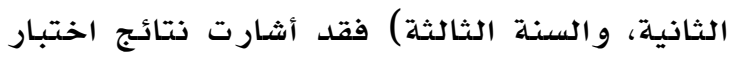

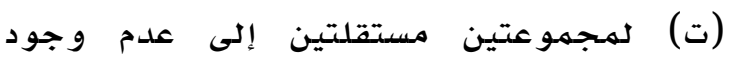
فروق ذات دلالة إحصائية في قياس درجة رضئ رضئ

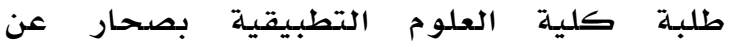

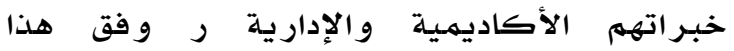

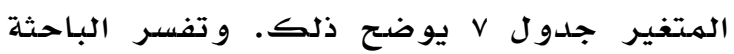
ذلك إلى أن الكلية تقدم خدماتها الأكاديمية

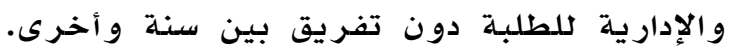

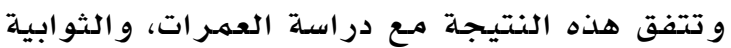

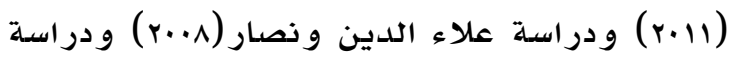
بو مـاه (Boamah, 2009).

أما بالنسبـة لهتغير المعدل التراكمي (جيد جدا،

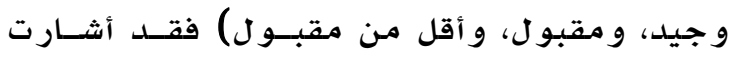

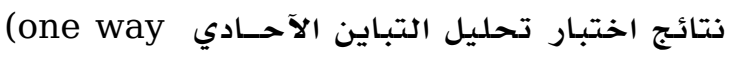

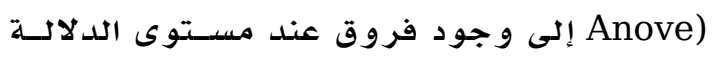

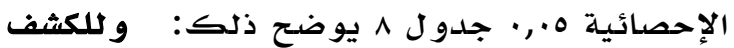

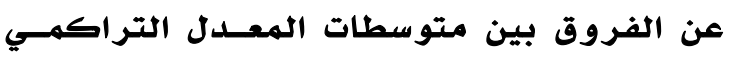
على مقياس درجـة رضـا طلبــة كليـة العلــوم

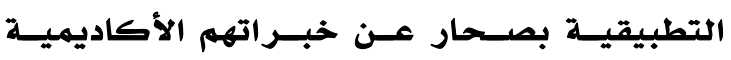
والإدارية تم استخدام اختبار ثفيه وبينت نتائجه و جود فروق داله احصائياً بين فئة جيد جداً و وفئة

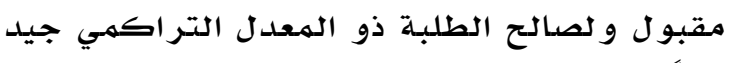

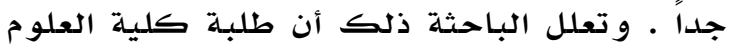

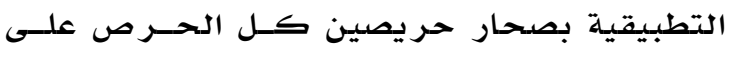

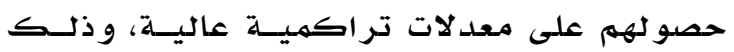


في كليات التربية في جامعات أردنية من وجهة نظر الطلبة، رسالة ماجسـتير غيـر منشورة، جامعة اليرموك، الأردن.

بوبشيت، الجوهرة إبــر اهيم، و الحمهـادي، فــايزة،

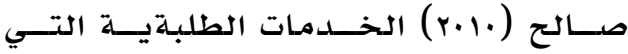

تقــدمها عمــادة شــئؤون الطلبــة: و اقعهـا

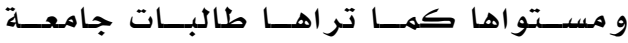

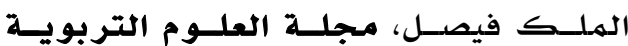

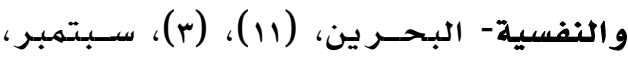
. YNT-YT\&

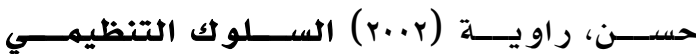
المعاصر ، الأسكندرية، الدار الجامعيلة.

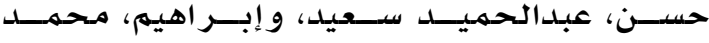

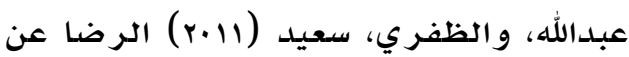

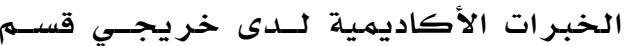

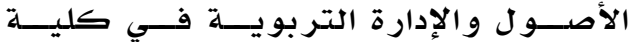

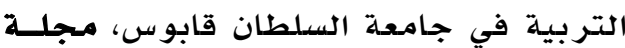

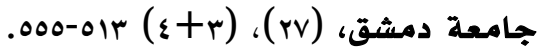

الحسينه، سليهم إبر اهيهم (q...r) مدى رضا طلبــة

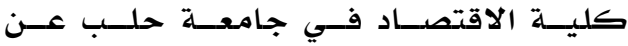

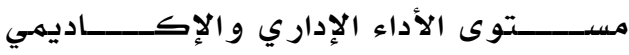

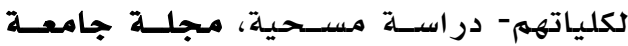
دمشق للعلوم الاقتصادية والقانونية، (ro)، .rו1-r^o، (r)

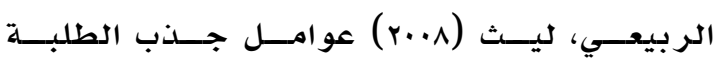

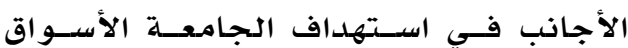

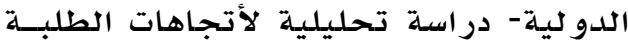

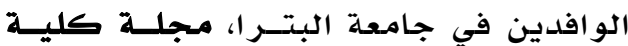

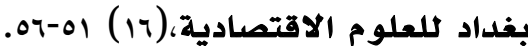

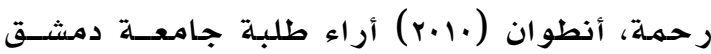

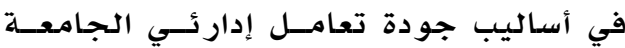
و أعضداء هيئاتها التعليمية مـع طلبتها، و في

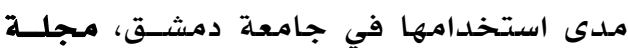
اتحاد الجامعات العربيـة للتربيـة وعلـم

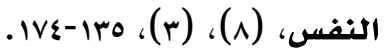

سليمان، شاهر خالد (·r.r) قياس جـودة الحيـاة لدى عينة من طلبـة جامعة تبو ك بالمـملكة العربية السعودية و تأثير بعض المتغيـر ات
الضعف وهي مجال التدريس، و الخــدمات الأكاديمية المساندة و الإدارية.

ب- القيام بتحسين أسـاليب التدريس وطـرق

التعلــيم، وعقــد دورات متتخصصــة فــي

أساليب طرق التدريس الجـامعي لـلأستاذ،

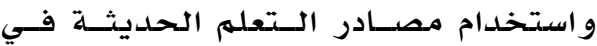
عمليتي التعلهم و التعليهم.

ع- العهـل علــى تحسـين شــبكات الإنتر نست

وسرعة الاتصـال لتــدفق المعلومسـات فـي

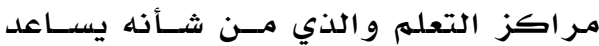
على السر عة في البـحث.

ه- قيام مركز التوجيه و التدريب الوظيفي

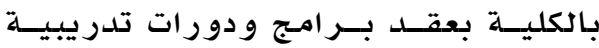
مهنية للطالب تساعده على ربط الإطـار

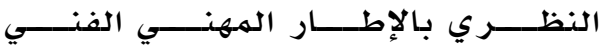
و التخصصي. ج- نظراً لمــا يتــوفر لمقيــاس الرضـا عـن الخبر ات الأكاديميسة والإداريسة بلدرجـــة

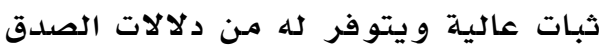
فإن الباحثة توصي بتطبيقه علـى طلبــة

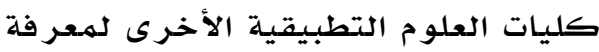

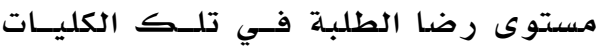

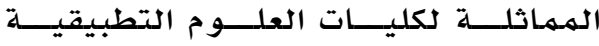

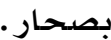

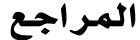

\section{References}

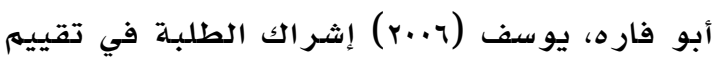

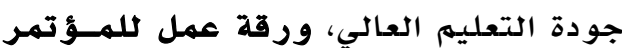

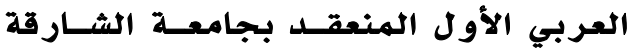

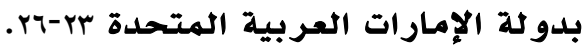

أبو قديس، محهـود (r...r) درجــة رضـا طلبــة

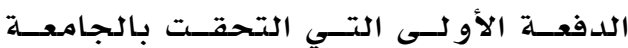

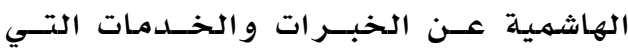

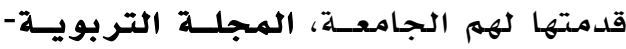

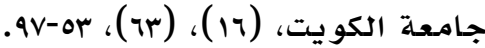

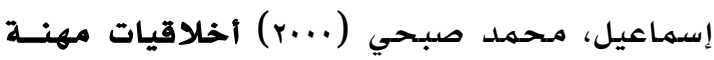
التعليه ومدى التزام أعضاء هيئة التدريس 
السودانية، دراسـة ميزانية، جامعة أفريقيـا

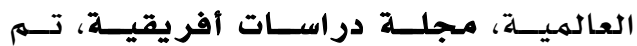

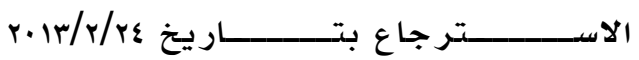
www.iue.edu.sdliuamagazin/african.145/003.doc.

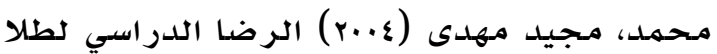
كلية التربية في جامعة إب، مجلة اتحسـاد

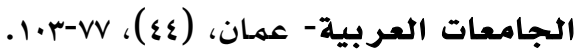
النبهان، موسـي (1990) دراســة تحليليسة لواقـع

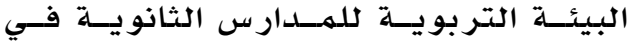

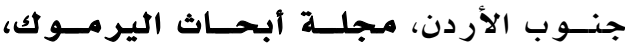
سلسلة العلوم الإنسانية والاجتماعية، ولاعية (11)، (1) (1)

النبهان، موسي (r..l) تطوير أداة لقياس درجــة

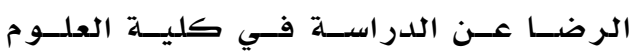

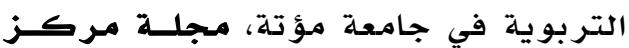

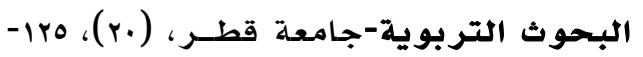
$.10 r$

النبهان، موسي (r.ll) تطوير أداة لقياس درجـة

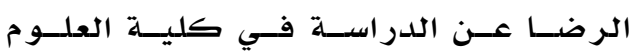

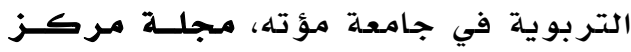

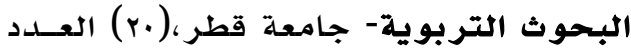
$.10 r-1$ ro (r.)

نصار، يحيي حياتي، و علاء الدين، جهاد محهمـود (r..人)

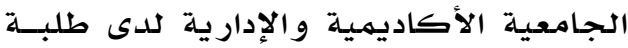

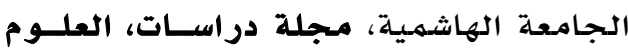

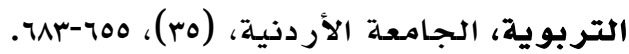

وزارة التعليم العالي، المديريـة العامــة لكليـات

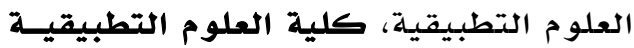

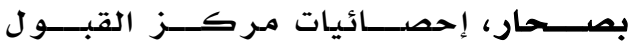

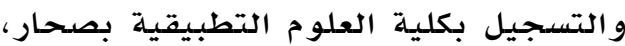
سلطنة عمان.

Boamah, J. (2009). the structure of student Satisfaction with college service: a latent class module, Alliant International university. Journal of Case Student in Education, 1-3.

Chen, C, \& Hughes, J. (2004). Using ordinal regression model to analyze student
عليها، مـجلة رسالة الخليج العربي-الرياض $-11 \mathrm{r},(11 \mathrm{~V})$

الشيزاوي، رقية محممد (^..r) أنمساط القيـادة

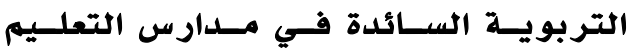

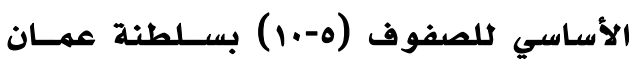

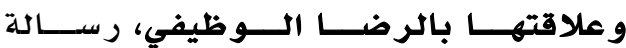

ماجستير غير منشورة، البحسـرين، جامعـة الخليـج العربي.

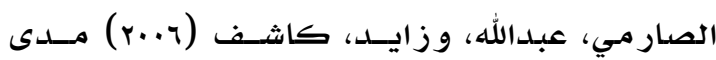
رضا طلبة كلية التربية بجامعة بلهة السـلطان

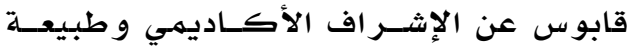

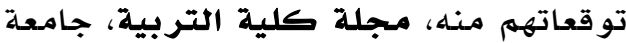

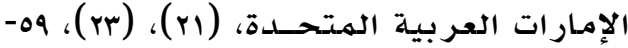

.$\Lambda$

الطويل، هاني عبدالرحمن (ه...r) إبدال في إدارة النظم التربوية- الإدارة بالإيمان، عمان، دار

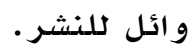

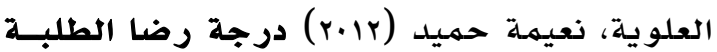

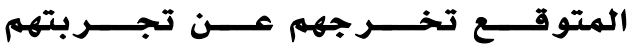

الأكاديمية في الجامعات الخاصة بسلطنة

عمسـان، رسـالة ماجسـتير غيـر منشــورة، جامعة صحار، سلطنة عمان.

عمـــار، حامــــ (1997) دراســات فـــي التربيــة

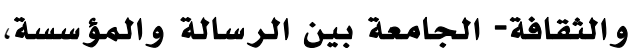
القاهرة، مكتبـة الدار العربية للكتاب.

العمر ات، مـحمد ســاله، الثوبيـه، أحمـــ مـحمــود

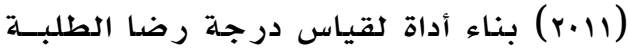

عن الدراسة في جامعــة الطفيلـهـ التقنيـة،

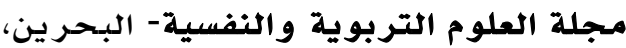

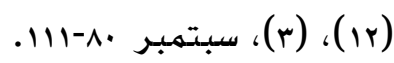

الغــافري، حهــد حمـود (r...r) مشـكلات طلبــة جامعة السلطان قابوس وعلاقتهـا بـبعض من

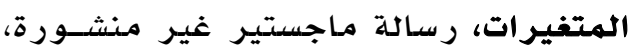
جامعسـة السـلطـان قـابوس، سـلطنـة عمــان، مسقط.

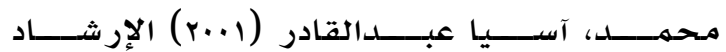

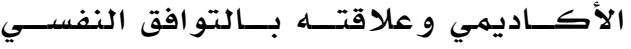

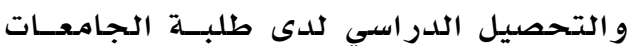


satisfaction questionnaires association for institutional research, 26, 1-10.

Clems, M., Gan, C., \& Tzu-hun, K. (2007). University student satisfaction: an empirical analysis. Journal of Marketing for Higher Education, 17 (2), 292-325

Harvey, L. (2003). Student Feedback. Quality in Higher education, 9, 3-20.

Kara, A., \& Deshied, O. W. (2004). Business Student Satisfaction, Intentions and Retention in Higher Education: An Empirical Investigation, Pennsylvanin State University- York Campus.

Kotler, P. (2001). Marketing management analysis planning, implement and control, India, Prntice Hall, inc.

Zhange, L., Han, Z. \& GAO, Q. (2008). Empirical study on the student satisfaction index in higher education. International Journal of Business and Management, 3, 46-51. 